\title{
Pore Fluid Chemistry Beneath Active Hydrothermal Fields in the Mid-Okinawa Trough: Results of Shallow Drillings by BMS During TAIGA11 Cruise
}

\author{
Jun-ichiro Ishibashi, Youko Miyoshi, Kazuya Tanaka, Eriko Omori, Yoshio \\ Takahashi, Yoshiko Furuzawa, Toshiro Yamanaka, Shinsuke Kawagucci, \\ Junichi Miyazaki, Uta Konno, Shota Watanabe, Katsunori Yanagawa, \\ Ryoto Yoshizumi, and Tetsuro Urabe
}

\begin{abstract}
TAIGA11 cruise of R/V Hakurei-maru No.2 was conducted in June, 2011 to study subseafloor geochemical environment below active hydrothermal fields using a shallow drilling system BMS (Benthic Multi-coring System). Three active hydrothermal fields were selected as target fields; the Iheya North Knoll field $\left(27^{\circ} 47^{\prime} \mathrm{N}, 126^{\circ} 54^{\prime} \mathrm{E}\right)$, the Jade field in the Izena Hole $\left(27^{\circ} 16^{\prime} \mathrm{N}, 127^{\circ} 05^{\prime} \mathrm{E}\right)$, and the Hakurei field in the Izena Hole $\left(27^{\circ} 15^{\prime} \mathrm{N}\right.$, $127^{\circ} 04^{\prime} \mathrm{E}$ ). In this chapter, we will report chemical composition and isotope ratios of pore fluids extracted from collected sediments. At the Hakurei field in the Izena Hole, BMS drilling attained to $610 \mathrm{cmbsf}$ ( $\mathrm{cm}$ below the seafloor) in the vicinity of a large massive sulfide mound. The obtained core showed evidence for sulfide and sulfate mineralization below $223 \mathrm{cmbsf}$. Pore fluid from the corresponding depth showed enrichment in $\mathrm{Si}$, K and $\mathrm{Ca}$, which could be attributed to influence of formation of alteration minerals rather than to involvement of the hydrothermal component. At the Jade field in the Izena Hole, BMS drilling attained to $529 \mathrm{cmbsf}$ at about $300 \mathrm{~m}$ apart from the area where high temperature fluid venting congregate. The obtained core comprised grayish white hydrothermal altered mud below $370 \mathrm{cmbsf}$, although pore fluid showed seawater like composition. At the Iheya North Knoll field, BMS drilling attained to $453 \mathrm{cmbsf}$ at about $200 \mathrm{~m}$ apart from the central mound area. The obtained core consisted almost entirely of grayish white hydrothermally altered mud. Pore fluid below $180 \mathrm{cmbsf}$ showed substantial enrichment in major cations $(\mathrm{Na}, \mathrm{K}, \mathrm{Ca}$ and $\mathrm{Mg}$ ) and $\mathrm{Cl}$, which would be explained as a result of hydration during hydrothermal alteration.
\end{abstract}

The online version of this chapter (doi:10.1007/978-4-431-54865-2_42) contains supplementary material, which is available to authorized users.

J.-i. Ishibashi $(\bowtie)$

Faculty of Sciences, Kyushu University, Fukuoka, Japan

e-mail: ishibashi.junichiro.779@m.kyushu-u.ac.jp

Y. Miyoshi

Graduate School of Sciences, Kyushu University, Fukuoka, Japan

Institute for Geo-Resources and Environment, AIST, Tsukuba, Japan

K. Tanaka

Institute for Sustainable Sciences and Development, Hiroshima

University, Higashihiroshima, Japan

E. Omori • Y. Takahashi

Graduate School of Science, Hiroshima University,

Higashihiroshima, Japan

Y. Furuzawa $\bullet$ T. Yamanaka

Graduate School of Natural Science, Okayama University,

Okayama, Japan

S. Kawagucci • J. Miyazaki • U. Konno

Department of Subsurface Geobiological Analysis and Research (D-SUGAR), Research and Development (R\&D) Center for Submarine Resources, Japan Agency for Marine-Earth Science and Technology (JAMSTEC), Yokosuka, Japan

S. Watanabe

Graduate School of Life and Environmental Sciences,

University of Tsukuba, Tsukuba, Japan

K. Yanagawa • R. Yoshizumi • T. Urabe Graduate School of Science, the University of Tokyo, Tokyo, Japan 
Keywords

Clay minerals - Hydration - Hydrothermal alteration • Hydrothermal component

- Sulfate reduction

\subsection{Introduction}

Many of active seafloor hydrothermal systems in the Okinawa Trough are considered to develop within sediment layers basically consist of volcanic and terrigenous material (Ishibashi et al., Chap. 27). Previous studies reported piles of tubular pumiceous sediment on volcanic knolls in the Okinawa Trough (e.g. Kato 1987). Porous volcanic sediment would stimulate subseafloor fluid flow within sediment layers that bears a hydrothermal system. Seafloor drilling during IODP (Integrated Ocean Drilling Program) Expedition 331 demonstrated existence of a hydrothermal fluid reservoir of laterally extensive in a kilometer scale in the volcanic sediment layers on the Iheya North Knoll in the Okinawa Trough (Takai et al. 2012). Significant fluid-mineral interactions are expected to occur within a hydrothermal system at such geological environment.

Hydrothermal activities in the Okinawa Trough are recognized as "TAIGA of methane", since their geochemical characteristics are represented by enrichment in organicderived species such as $\mathrm{CH}_{4}, \mathrm{NH}_{3}$ and $\mathrm{H}_{2}$ (Kawagucci, Chap. 30). These species are considered to be derived from microbiological and thermal decomposition of organic material within the sediment layer during fluid circulation in the recharge and discharge regions (Kawagucci et al. 2013). In addition to them, significant input of magmatic volatiles such as $\mathrm{CO}_{2}$ and $\mathrm{H}_{2} \mathrm{~S}$ into the hydrothermal fluid has been commonly recognized among hydrothermal systems in the Okinawa Trough (e.g. Ishibashi and Urabe 1995). Involvement of these volatile and/or organic-derived species into pore fluid would substantially control $\mathrm{pH}$ of the fluid.

A Benthic Multi-coring System (BMS) is a powerful tool to directly access the subseafloor environment (e.g. Marumo et al. 2008). Although it may be difficult to penetrate the fluid reservoir even with the maximum capacity, drilling by the BMS is accessible to a region where various interactions are expected to be induced by mixing between the hydrothermal component and entrained seawater. We conducted BMS drilling in the Okinawa Trough from May 31 to June 9 in 2011, during TAIGA11 cruise of R/V Hakurei-Maru No.2. Purpose of the BMS drilling is to reveal evidence for various hydrothermal interactions within sediment layers based on geochemical, mineralogical, microbiological analysis of the obtained core samples. In this chapter, we will describe records of the BMS operations and report visual core descriptions (VCD) of the obtained core samples and geochemistry of pore fluids extracted from them. Mineralogical studies on the core samples will be reported in other chapters in this volume (Miyoshi et al., Chap. 44; Yoshizumi et al., Chap. 43).

\subsection{Methodology}

\subsubsection{Core Sampling Device}

A Benthic Multi-coring System (BMS) is a remotely operated seafloor coring system connected via armored umbilical cable to a control console on the support ship R/ V Hakurei-Maru No.2 (Fig. 42.1a). This system has $5.5 \mathrm{~m}$ in height, $4.4 \mathrm{~m}$ in length, $3.6 \mathrm{~m}$ in width and 3.9 ton in weight. Figure $42.1 \mathrm{~b}$ illustrates configuration of the BMS. The BMS has a rotating storage magazine for the drilling equipment (core barrels, drilling rods, and casing pipes) that enables it to core to depths of up to $20 \mathrm{~m}$ in $2.2 \mathrm{~m}$ intervals. The core barrel (modified version of the NC core barrel) is a doubletube, thin-kerf diamond-bit core barrel that allows for recovery of $49 \mathrm{~mm}$ diameter core in consolidated soft and/or hard rock formations. The BMS is equipped with five TV cameras to help search for appropriate drilling sites and to monitor working tools during the drilling operation. The drill bit is usually cooled with seawater. During TAIGA11 cruise, a large-volume, multi-step filtration system was installed on the intake side of the bit cooling system to achieve aseptic drilling. Measurements of temperature within boreholes (up to $300{ }^{\circ} \mathrm{C}$ ) were conducted using a fully mechanical system embedded in the core barrel. Titanium tubing was prepared for casing some of the drilled holes.

Other than the BMS, a gravity corer (called as LC corer in this cruise) was employed for coring when the sea condition was not good enough for BMS operation. The LC corer is equipped with a $4 \mathrm{~m}$ long core barrel and $0.3 \mathrm{~m}$ extension installed core catchers.

\subsubsection{Core Sampling Operations}

Target study fields of the TAIGA11 cruise were selected from active hydrothermal fields in the mid-Okinawa Trough (Fig. 42.2a). Table 42.1 summarizes coring operations during the TAIGA11 cruise conducted in June, 2011. In total, eight BMS operations and two LC core (gravity core) samplings were conducted. Operation hours of the BMS 


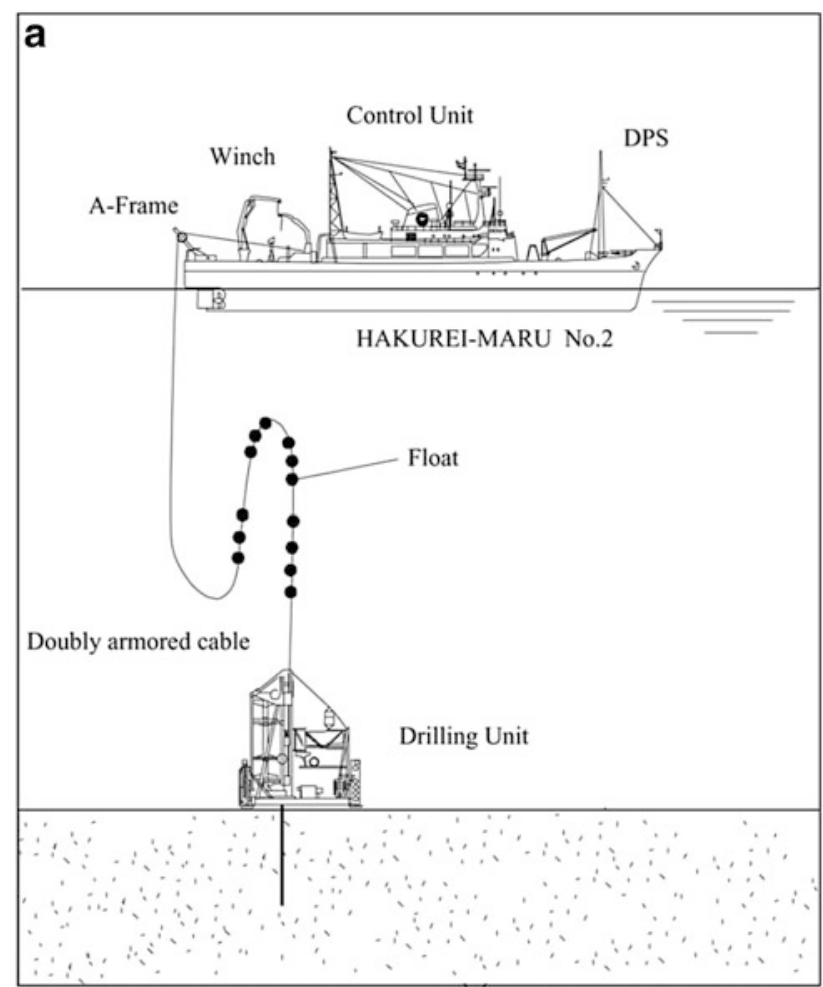

Fig. 42.1 (a) Operation scheme of BMS (Benthic Multicoring System).

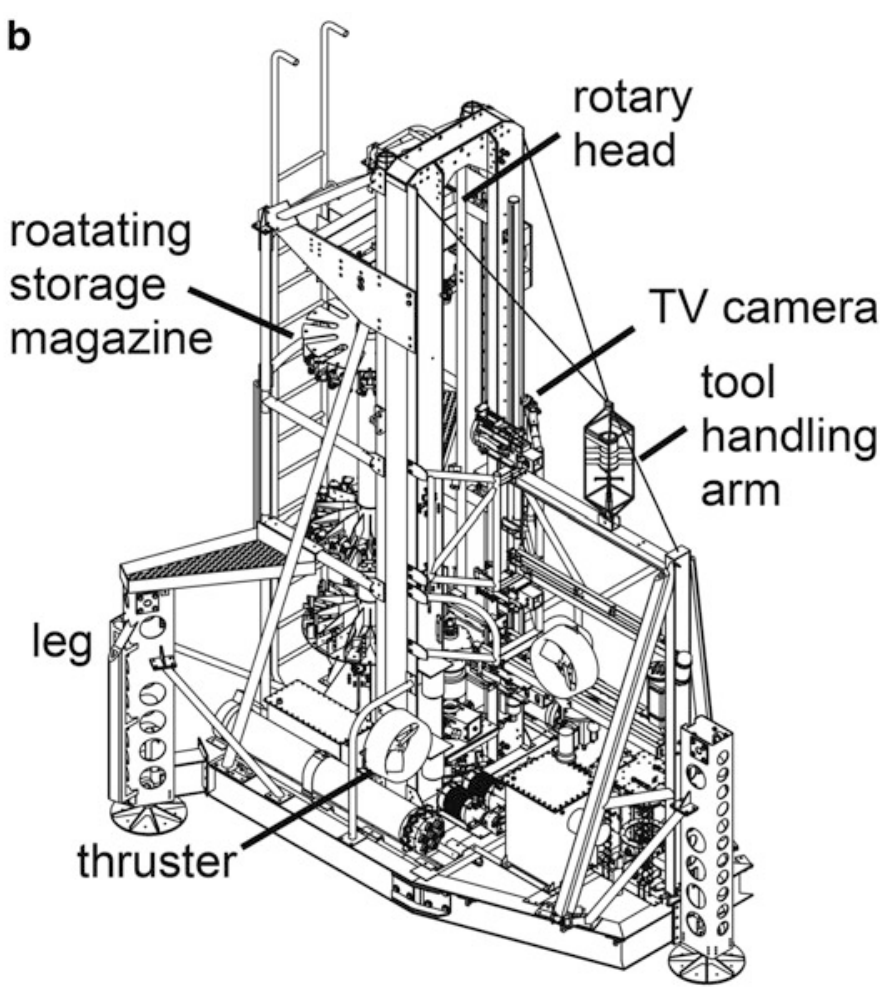

(b) Illustrated configuration of BMS (modified after Marumo et al. 2008) were sometimes restricted by bad sea condition and by approach of fishing boats.

In the Hakurei field in the Izena Hole, three BMS operations were conducted in Stations BMS-H-1, BMS-H-6A and BMSH-6B (Fig. 42.2b). Station BMS-H-1 was located at about $100 \mathrm{~m}$ west from a large sulfide mound which was recognized as the most prominent hydrothermal mound in the northern part of the Hakurei field. This area has been explored intensively by JOGMEC (Japan Oil, Gas and MEetals National Corporation) under a framework of the ocean energy and mineral resources development program. With visual observation by the monitoring camera, seafloor was recognized as covered with sediment including gravels of a few $\mathrm{cm}$ diameters, associated with white patches. Drilling at Station BMS-H-1 successfully attained to $610 \mathrm{cmbsf}$ (centimeters below the seafloor). Station BMS-H-6 was located at about $150 \mathrm{~m}$ northeast from the large sulfide mound. Drilling at Station BMS-H-6 was ceased due to a trouble in a rotary jaw when drilled to $33 \mathrm{cmbsf}$ (BMS-H-6A). Drilling was re-started after the repair at the same station (BMS-H-6B). However, due to limited time for operation, the drilling attained only to $341 \mathrm{cmbsf}$ and its core recovery was not good.

In the Jade field in the Izena Hole, four BMS operations were conducted at Stations BMS-J-2, BMS-J-3A, BMS-J-3B and BMS-J-5 (Fig. 42.2c). Station BMS-J-2 was located near the Biwako vent site where consolidated sediment with native sulfur was observed. With visual observation by the monitoring camera, seafloor was recognized as covered with large size of consolidated sediment blocks. After the drilling attained to $529 \mathrm{cmbsf}$, this hole was cased using two casing pipes. Station BMS-J-3 was located in the central area of the Jade field where high temperature fluid venting congregate around the TBS chimney. In this area, gravels of native sulfur were recovered by surface coring (Yokoyama et al., Chap. 31). Due to steep slope topography, the coring operation was limited to pushing the bit without rotation. The first trial attained to $151 \mathrm{cmbsf}$ (BMS-J-3A) and the second trial attained to $164 \mathrm{cmbsf}$ by rotating the bit slowly (BMS-J-3B). During the drillings, emanation of black-colored slime-like fluid from the seafloor about one meter apart from the drilled hole was observed. This hole was cased after the drilling. Station BMS-J-5 was located near the site of liquid $\mathrm{CO}_{2}$ bubble emanation, which was reported by Sakai et al. (1990). Several trials were required to deploy the BMS on the seafloor in stable condition. Only a short core $(30-40 \mathrm{~cm})$ was recovered due to plugging of the bit. In addition to the BMS operations, one LC core sampling was conducted at Station LC-J-2 located in the vicinity of the BMS-J-2.

In the Iheya North Knoll field, one BMS operation at Station BMS-I-4 and one LC core sampling at Station LC-I1 were conducted (Fig. 42.2d). Station BMS-I-4 was located between IODP Sites C0013 and C0014 (Takai et al. 2012). With visual observation by the monitoring camera, seafloor was recognized as covered with sediment associated with 


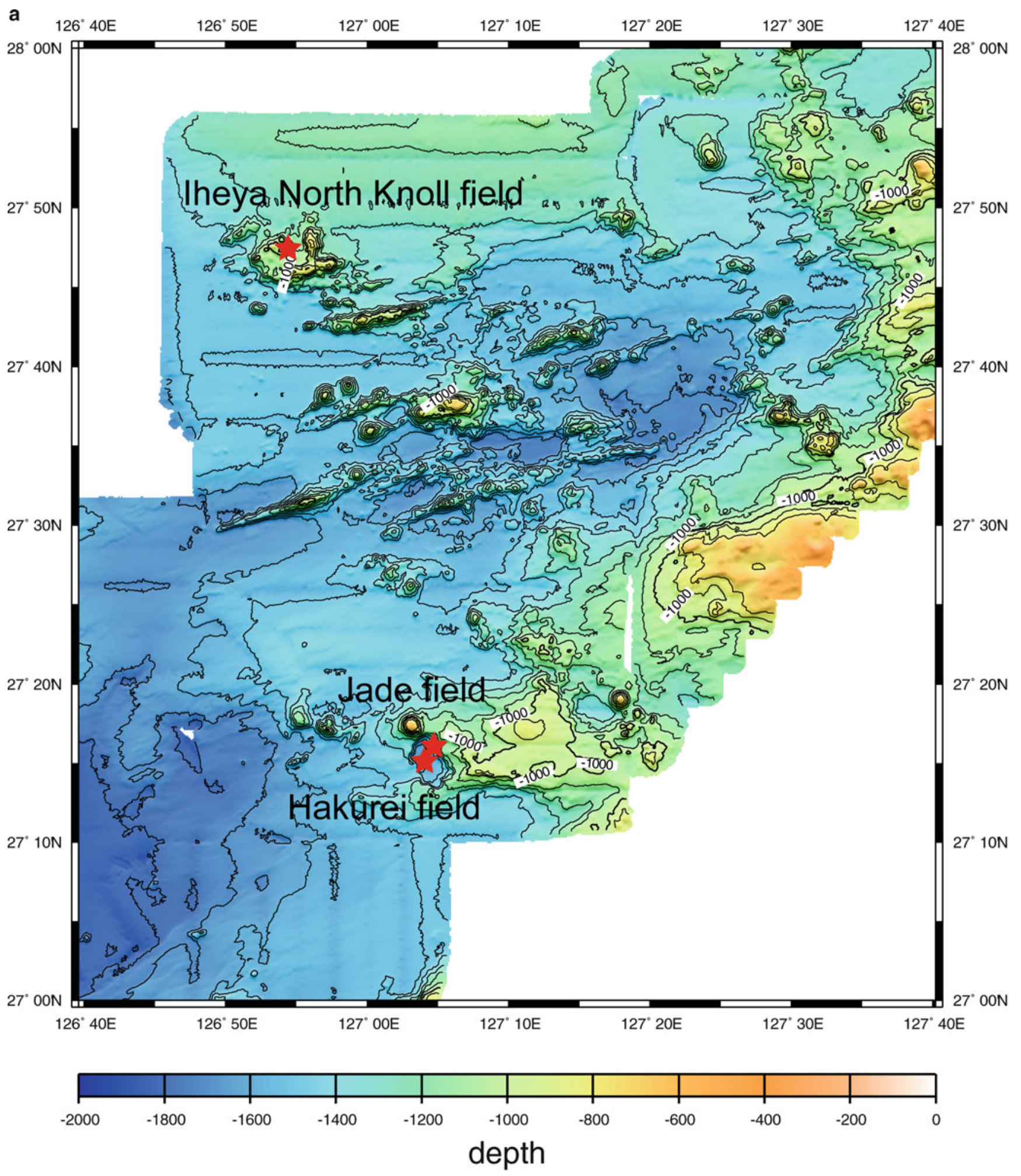

Fig. 42.2 Bathymetric maps of studied hydrothermal fields. Coring stations were superimposed on the maps. (a) Locality of the studied hydrothermal fields in the mid-Okinawa Trough. (b) Hakurei field in the Izena Hole. (c) Jade field in the Izena Hole. (d) Iheya North Knoll field 

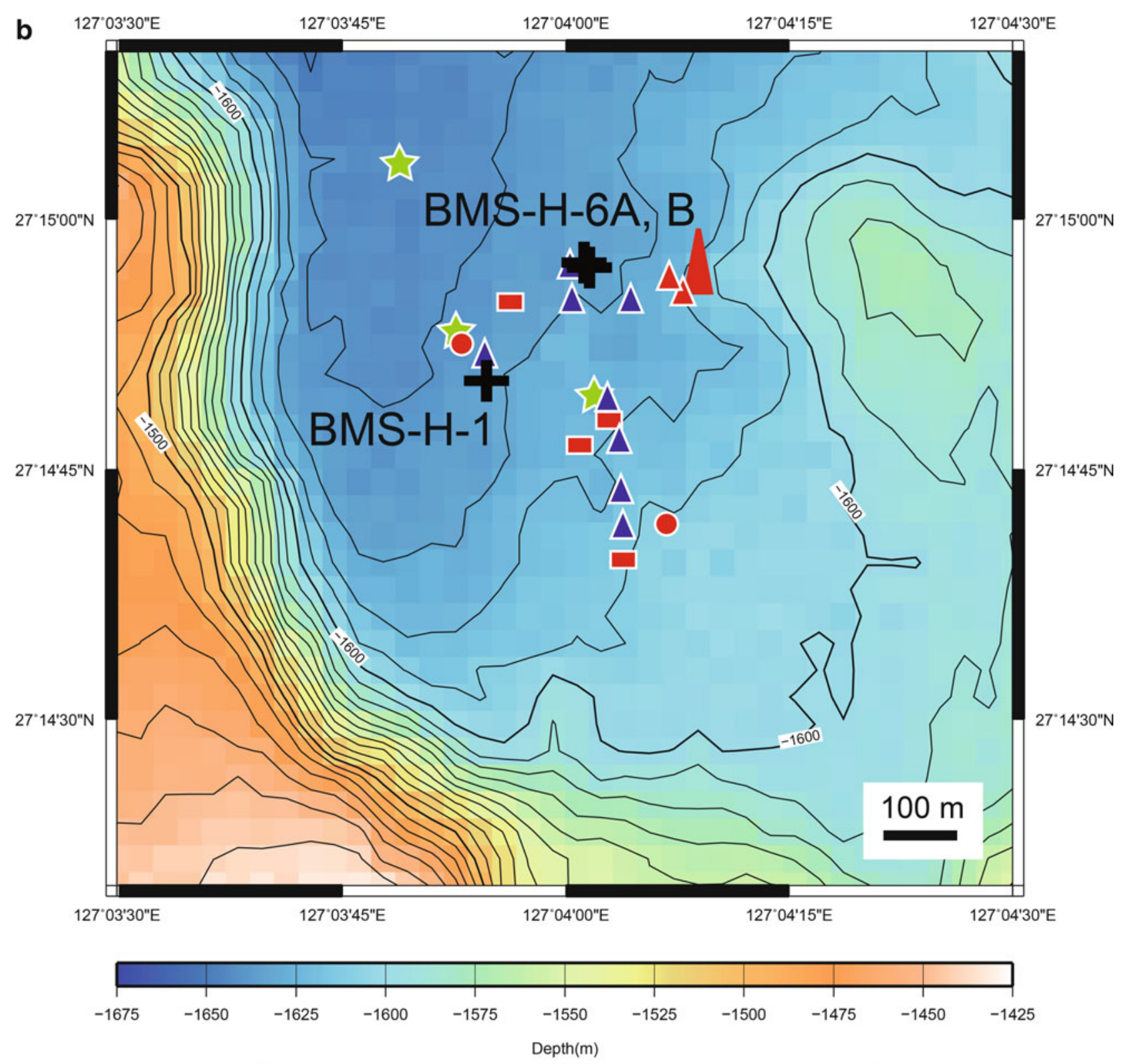

Highest temperature fluid vent (326oC, Dragon Chimney)

$\Delta$ High temperature fluid vent $(>200 \circ C) \wedge$ Siulfur crust

- Visible fluid flow vent

A Dead chimney

- Microbial mat / Animal colony

- Dead colony

Fig. 42.2 (continued) 

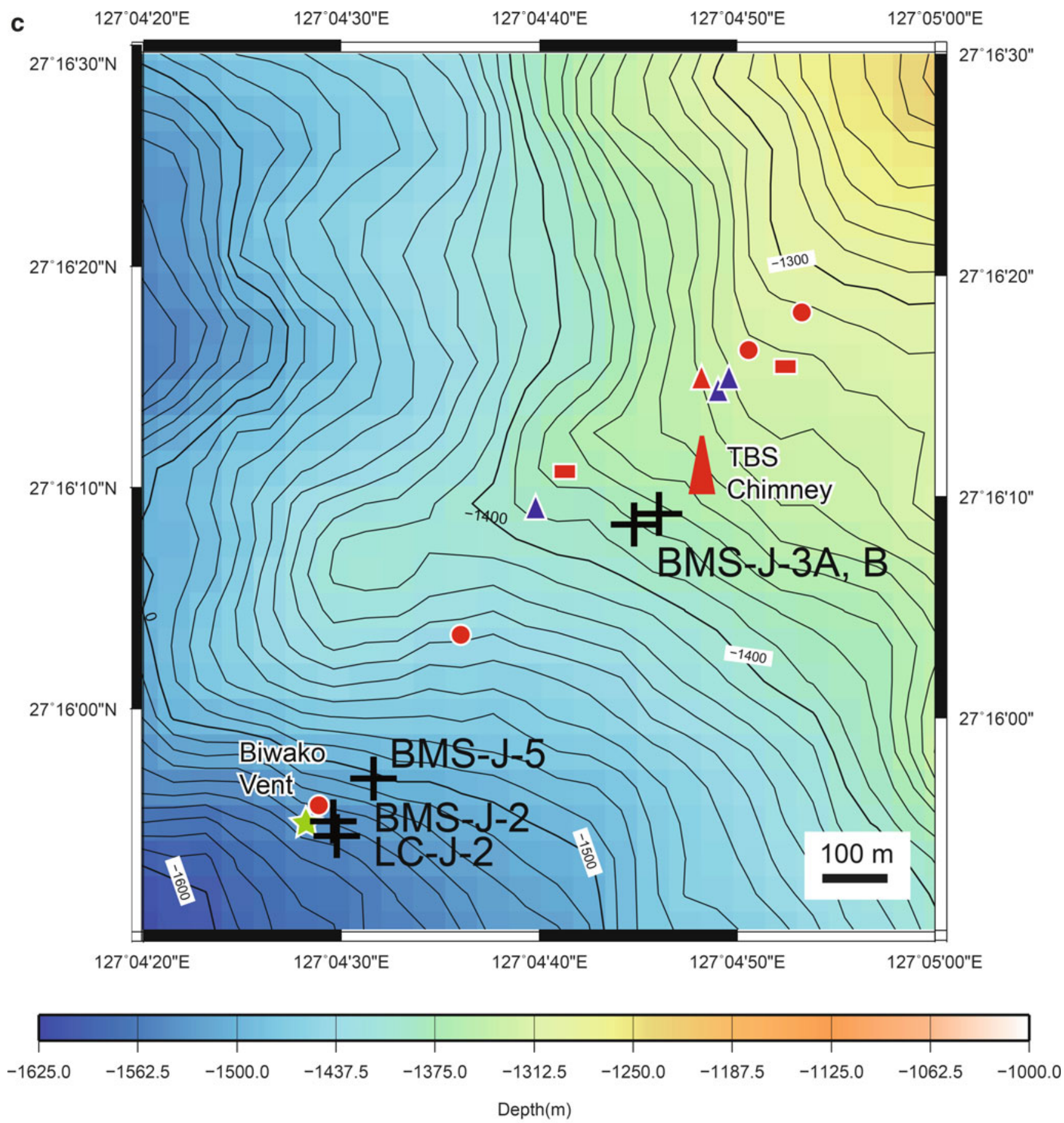

Highest temperature fluid vent (320oC, TBS Chimney)

$\Delta$ High temperature fluid vent $(>200 \circ C) \star$ Siulfur crust

- Visible fluid flow vent

A Dead chimney

- Microbial mat / Animal colony

- Dead colony

Fig. 42.2 (continued) 


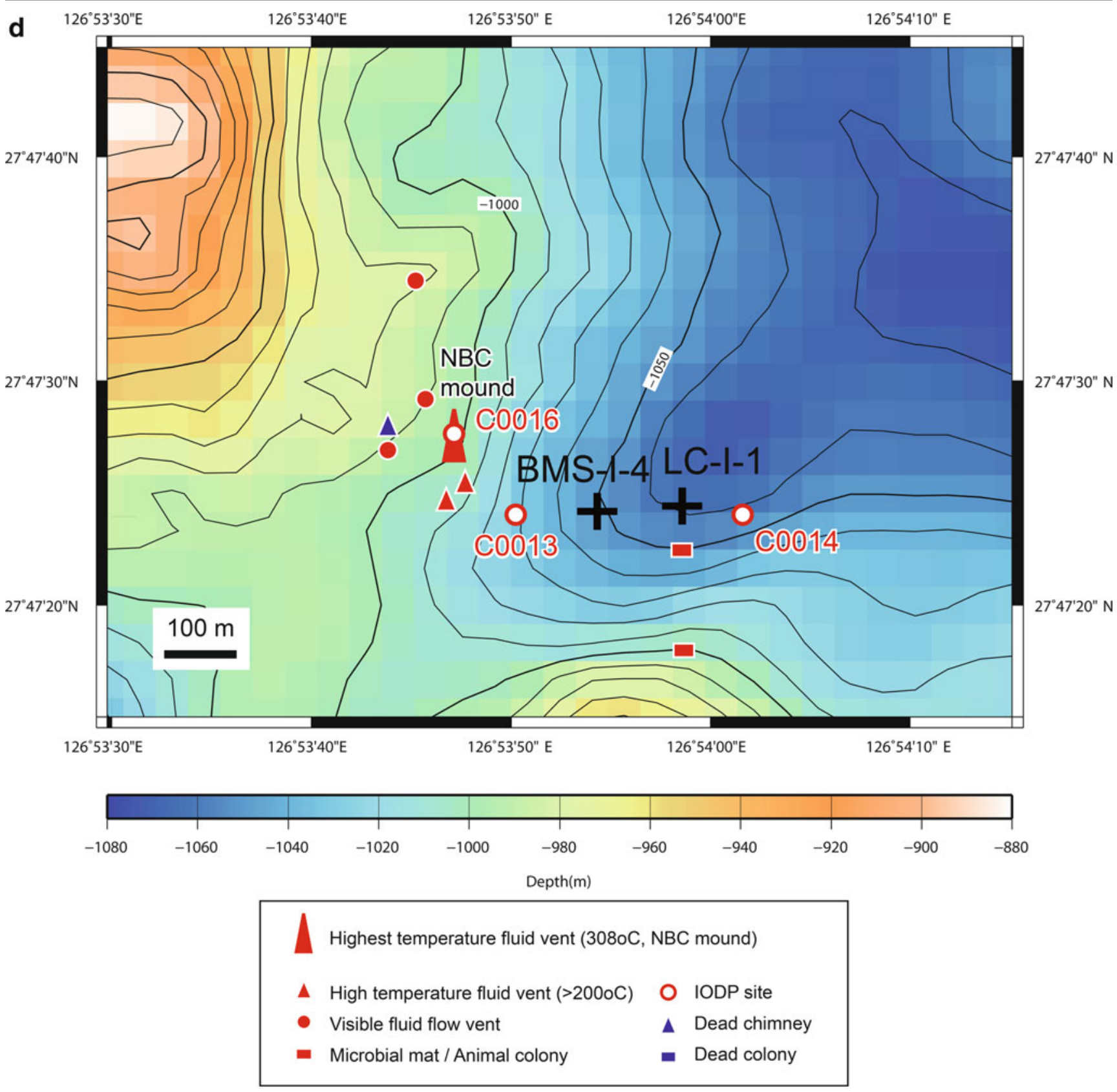

Fig. 42.2 (continued)

bacterial mat and clam shells. During the drilling below $17 \mathrm{cmbsf}$, emanation of white-colored slime-like fluid from the seafloor around the drilled hole was observed. During the drilling from 80 to $144 \mathrm{cmbsf}$, substantially less resistance was monitored and the slime-like fluid emanation was ceased. Emanation of slime-like fluid started again when the drilling below $170 \mathrm{cmbsf}$ started, and more dense white-colored slime was observed when the drilling attained to $336 \mathrm{cmbsf}$. The drilling operation was stopped at $453 \mathrm{cmbsf}$ where high resistance was monitored. After the drilling, borehole temperature measurement was conducted and followed by casing. Emanation of liquid bubbles every a few seconds from the top of the casing pipe was observed when the BMS left the seafloor. Station LC-I-1 was located between Station BMS-I-4 and Site C0014 (Fig. 42.2d).

\subsubsection{Handling of Core Samples}

As soon as the BMS was returned to onboard, core barrels were removed from the rotating storage magazine. After a core catcher was removed, core inside the core barrel was pushed out slowly using hydrostatic pressure, which was applied by pumping filtered seawater into the other end. 
Table 42.1 Summary of core sampling operations during TAIGA11 cruise

\begin{tabular}{|c|c|c|c|c|c|c|c|c|c|}
\hline \multirow[b]{2}{*}{ Drilling site } & \multirow[b]{2}{*}{ Date } & \multirow[b]{2}{*}{ Device } & \multicolumn{2}{|l|}{ Position $^{a}$} & \multirow{2}{*}{$\begin{array}{l}\text { Water } \\
\text { depth }^{\mathrm{b}}(\mathrm{m})\end{array}$} & \multirow{2}{*}{$\begin{array}{l}\text { Drilled } \\
\text { depth }(\mathrm{cm})\end{array}$} & \multirow{2}{*}{$\begin{array}{l}\text { Core } \\
\text { length }(\mathrm{cm})\end{array}$} & \multirow{2}{*}{$\begin{array}{l}\text { Core } \\
\text { recovery }(\%)\end{array}$} & \multirow{2}{*}{$\begin{array}{l}\text { Casing } \\
\text { pipe }\end{array}$} \\
\hline & & & Latitude & Longitude & & & & & \\
\hline \multicolumn{10}{|l|}{ HAKUREI field, Izena Hole } \\
\hline TAIGA11-BMS-H-1 & $6 / 1 / 2011$ & BMS & $27^{\circ} 14.837^{\prime} \mathrm{N}$ & $127^{\circ} 03.911^{\prime} \mathrm{E}$ & 1,661 & 610.4 & 389.0 & 63.7 & No \\
\hline TAIGA11-BMS-H-6A & $6 / 8 / 2011$ & BMS & $27^{\circ} 14.950^{\prime} \mathrm{N}$ & $127^{\circ} 04.025^{\prime} \mathrm{E}$ & 1,661 & 32.9 & 21.0 & 63.8 & No \\
\hline TAIGA11-BMS-H-6B & $6 / 8 / 2011$ & BMS & $27^{\circ} 14.955^{\prime} \mathrm{N}$ & $127^{\circ} 04.019^{\prime} \mathrm{E}$ & 1,660 & 341.1 & 109.0 & 32.0 & No \\
\hline \multicolumn{10}{|l|}{ JADE field, Izena Hole } \\
\hline TAIGA11-BMS-J-2 & $6 / 2 / 2011$ & BMS & $27^{\circ} 15.913^{\prime} \mathrm{N}$ & $127^{\circ} 04.495^{\prime} \mathrm{E}$ & 1,520 & 529.1 & 366.7 & 69.3 & Yes \\
\hline TAIGA11-BMS-J-3A & $6 / 3 / 2011$ & BMS & $27^{\circ} 16.146^{\prime} \mathrm{N}$ & $127^{\circ} 04.746^{\prime} \mathrm{E}$ & 1,396 & 151.7 & 103.0 & 67.9 & No \\
\hline TAIGA11-BMS-J-3B & $6 / 3 / 2011$ & BMS & $27^{\circ} 16.154^{\prime} \mathrm{N}$ & $127^{\circ} 04.767^{\prime} \mathrm{E}$ & 1,383 & 164.6 & 44.0 & 26.7 & Yes \\
\hline TAIGA11-BMS-J-5 & $6 / 6 / 2011$ & BMS & $27^{\circ} 15.956^{\prime} \mathrm{N}$ & $127^{\circ} 04.526^{\prime} \mathrm{E}$ & 1,543 & 75.6 & 27.0 & 35.7 & No \\
\hline TAIGA11-LC-J-2 & $6 / 6 / 2011$ & $\mathrm{LC}$ & $27^{\circ} 15.924^{\prime} \mathrm{N}$ & $127^{\circ} 04.492^{\prime} \mathrm{E}$ & 1,570 & 330.0 & 310.0 & 93.9 & - \\
\hline \multicolumn{10}{|l|}{ Iheya North Knoll field } \\
\hline TAIGA-BMS-I-4 & $6 / 4 / 2011$ & BMS & $27^{\circ} 47.404^{\prime} \mathrm{N}$ & $126^{\circ} 53.906^{\prime} \mathrm{E}$ & 1,048 & 453.4 & 157.0 & 34.6 & Yes \\
\hline TAIGA11-LC-I-1 & $6 / 5 / 2011$ & $\mathrm{LC}$ & $27^{\circ} 47.408^{\prime} \mathrm{N}$ & $126^{\circ} 53.977^{\prime} \mathrm{E}$ & 1,048 & 230.0 & 230.0 & 100.0 & - \\
\hline
\end{tabular}

${ }^{a}$ Position of the drilling site was determined based on GPS data of the ship

${ }^{\mathrm{b}}$ Water depth of the drilling site was determined based on MBES data

Then, the core was delivered on an acrylic tubing of a half cylinder shape which was sterilized with alcohol beforehand. Since length of the acrylic tubing was shorter than that of the core barrel, the core was sometimes divided into a few sequentially numbered sections.

As soon as the LC corer returned to onboard, an acrylic inner tubing that had been inserted into a gravity corer was drawn out. Then, the core was divided into two half cylinders using a cutter and gut.

In either case, core samples were laid on a table in the main laboratory of R/V Hakurei-Maru No.2 and photographed. Sampling of sub-samples for each specific study was conducted in parallel to description of the core by visual observation. After all the sub-sampling and description works completed, remained cores were divided by every $10-30 \mathrm{~cm}$ length and packed in plastic bags for storage.

\subsubsection{Chemical Analysis of Pore Fluid}

Pore fluid was extracted from the sediment sub-samples onboard employing two techniques. One is the standard ODP (Ocean Drilling Project) method using a hydraulic sediment press (Manheim and Sayles 1974). The other is an easy-to-use technique using a plastic syringe and small vice (Nakaseama et al. 2008). The latter technique has an advantage of quick handling but a disadvantage of limitation of sample volume (about $30 \mathrm{~cm}^{3}$ of sediment). In either case, the extraction of pore fluid was conducted within $48 \mathrm{~h}$ after the sample recovery.

Chemical analysis of pore fluids for some unstable species was conducted onboard, basically following the protocol adopted by ODP (Ocean Drilling Project) expeditions (Gieskes et al. 1991). Measurement of $\mathrm{pH}$ was conducted onboard using a $\mathrm{pH}$ electrode at room temperature. Titration alkalinity was determined onboard following the Gran's method. Conventional colorimetric techniques were employed for analysis of $\mathrm{Si}$ by the molybdenum blue method, of $\mathrm{NH}_{4}$ by indophenol method, and of $\mathrm{H}_{2} \mathrm{~S}$ by methylene blue method. Analytical precision was estimated to be within $3 \%$ relative error for $\mathrm{Si}$ and $\mathrm{NH}_{4}$ based on repeated analysis of artificial seawater. Analytical precision was worse for $\mathrm{H}_{2} \mathrm{~S}$ due to the volatile and unstable property, and $\sim 10 \%$ discripancy was sometimes recognized for duplicate analysis of the same sample.

Other major chemical species were analyzed on-shore laboratories in Kyushu University and Okayama University. Concentration of $\mathrm{Cl}$ was determined by $\mathrm{AgNO}_{3}$ titration following the Mohr method. Concentration of $\mathrm{SO}_{4}$ was determined by an ion chromatograph (Dionex, DX-100) after 300 times dilution. Concentration of $\mathrm{K}$ was analyzed by an atomic absorption spectrophotometer (Perkin Elmer, AAnalyst 100) after 200 times dilution of the acidified subsamples with addition of $\mathrm{Cs}$. Concentrations of $\mathrm{Mg}$ and $\mathrm{Ca}$ were determined by ICP-AES (Seiko Instruments, SPS1200AR) after 200 times dilution of the acidified subsamples. Concentration of $\mathrm{Na}$ was calculated from the charge balance between these major cations and anions. Discrepancy between the calculated $\mathrm{Na}$ concentration and determined Na concentration by ICP-AES was less than $5 \%$ for most of samples. Analytical precision for each chemical analysis was estimated to be within $\pm 3 \%$ relative error from replicate analysis.

Head space gas analysis was conducted only for the BMS-I-4 core. For this purpose, appropriate volume $\left(\sim 2 \mathrm{~cm}^{3}\right)$ of sediment was subsampled into an $8 \mathrm{ml}$ glass vial capped by a butyl-rubber septum under the atmosphere after addition of $0.2 \mathrm{ml} \mathrm{HgCl}_{2}$-saturated solution for 
sterilization. After three months storage at $-20{ }^{\circ} \mathrm{C}$, concentrations of $\mathrm{CH}_{4}$ and $\mathrm{H}_{2}$ in head space of the vial were determined with a gas chromatograph equipped with a helium ionization detector. Together with a result of weighing sediment in the vial, gas content in the sediment was calculated. Detection limit was about 5 ppmv of headspace for both gas species, which roughly corresponds to about $1 \mathrm{nmol} / \mathrm{g}$ sediment. Overall analytical error was estimated to be about $20 \%$.

Hydrogen and oxygen isotope ratios of $\mathrm{H}_{2} \mathrm{O}$ were determined by a wavelength scanned cavity ring down spectroscopy analyzer (Liquid Water Isotope Analyzer, Los Gatos Research, Inc.). Analytical precision was estimated to be within $\pm 1.0 \%$ o for $\delta \mathrm{D}$ value and $\pm 0.5 \%$ for $\delta^{18} \mathrm{O}$ value. Sulfur isotope ratios of dissolved $\mathrm{SO}_{4}$ were determined by EA/irMS (IsoPrime) following the precedure described in Yamanaka et al. (2008).

\subsubsection{Post-drilling Observation}

Two months after the BMS drilling during TAIGA11 cruise, a dive expedition of ROV Hyper-Dolphin was conducted during NT11-15 cruise. This cruise provided us a desirable opportunity to observe post-drilling feature of the drilled sites. During Dive 1310 of ROV Hyper-Dolphin in the Jade field, the top of the casing pipe at Station BMS-J-2 was witnessed. However fluid emanation was not observed. A locality of the drilled hole was confirmed as $27^{\circ} 15.919^{\prime} \mathrm{N}$, $127^{\circ} 04.489^{\prime} \mathrm{E}$, which is close to the position determined based on ship GPS data during the drilling. During Dive 1311 of ROV Hyper-Dolphin in the Iheya North Knoll field, more than one hour was occupied for exploration around the envisonal locality of Station BMS-I-4, however any signature of the drilled hole was not witnessed. We had no opportunity to observe post-drilling feature for Station BMS-J-3.

\subsection{Results and Discussion}

\subsubsection{Visual Core Description}

For the core samples obtained by the BMS, depths were determined in following way. At first, depths of the core tops were determined based on drilled length of the BMS that was monitored onboard. Then, depth intervals were assigned starting from the depth below seafloor at which coring started. Short cores due to incomplete recovery were all assumed to start from the initial depth determined as above way. For the core samples obtained by the LC, the core top was assumed as the seafloor depth and depth intervals were assigned. In either case, material recovered from the core catcher was placed at the bottom of the lowermost section of the recovered core.

Figure 42.3 summarizes a revised version of visual core descriptions (VCD) of the obtained cores. The VCD was originally noted onboard in parallel to sub-sampling procedure. The identified minerals onboard were confirmed or revised based on results of mineralogical analysis conducted after return to the laboratory (Miyoshi et al., Chap. 44). In followings, characteristic lithology for each core is summarized.

In the BMS-H-1 core, sulfide minerals were abundantly identified in several layers. Massive sulfides occupied from 0 to $20 \mathrm{cmbsf}$. Sulfidic grits were found below $223 \mathrm{cmbsf}$, underlain by barite and sphalerite mixed layer. Sphalerite was dominant among sulfide minerals in the layer from 339 to $370 \mathrm{cmbsf}$, whereas chalcopyrite was dominant from 370 to $417 \mathrm{cmbsf}$. Below $417 \mathrm{cmbsf}$ to the core catcher depth (530 cmbsf), barite was dominant again. The BMS-H-6B core mainly consisted of unaltered sediment including woody pumice.

Most part of the BMS-J-2 core (shallower than 381 cmbsf) was characterized by pumiceous sediment, and spotty white colored grains were noted in some layers. Below $381 \mathrm{cmbsf}$, the core consisted of hydrothermal mud including abundant clay minerals, which was continuous to the core catcher depth (423 cmbsf). In this layer, occurrence of pyrite and native sulfur was recognized. The BMS-J-3A core was characterized by sediment consisted of pumice, silt, sand and white-colored clay minerals and the BMS-J3B core showed similar signature. In the BMS-J-5 core, gravels of native sulfur were observed, which plugged the bottom of the corer. In the LC-J-2 core, hydrothermally altered pumice was recognized occasionally in olive brown colored silt and clay sediment. Plant debris was notable in the layer from 100 to $200 \mathrm{cmbsf}$. Below $300 \mathrm{cmbsf}$, the core consisted of grayish white colored hydrothermal mud, which was continuous to the core catcher depth (320 cmbsf). During sub-sampling onboard, gas bubbling from the sediment was observed.

In the BMS-I-4 core, evidence for hydrothermal alteration was notable in most entire part. Core of only $30 \mathrm{~cm}$ length was recovered during the first coring, and pyrite and clay minerals were found in it. Below $170 \mathrm{cmbsf}$, the obtained core was dominated by grayish white colored mud mostly consisted of kaolinite, which was continuous to the core catcher depth $(370 \mathrm{cmbsf})$. Together with the observation of white-colored slime-like fluid during the drilling operation, this intensely altered sediment layer was considered to have at least $2 \mathrm{~m}$ thickness. During subsampling onboard, gas bubbling from the sediment was observed, as well as detection of $\mathrm{H}_{2} \mathrm{~S}$ smell. The LC-I-1 core was characterized by silt and clay sediment which often included pumiceous material. Below 184 cmbsf, 


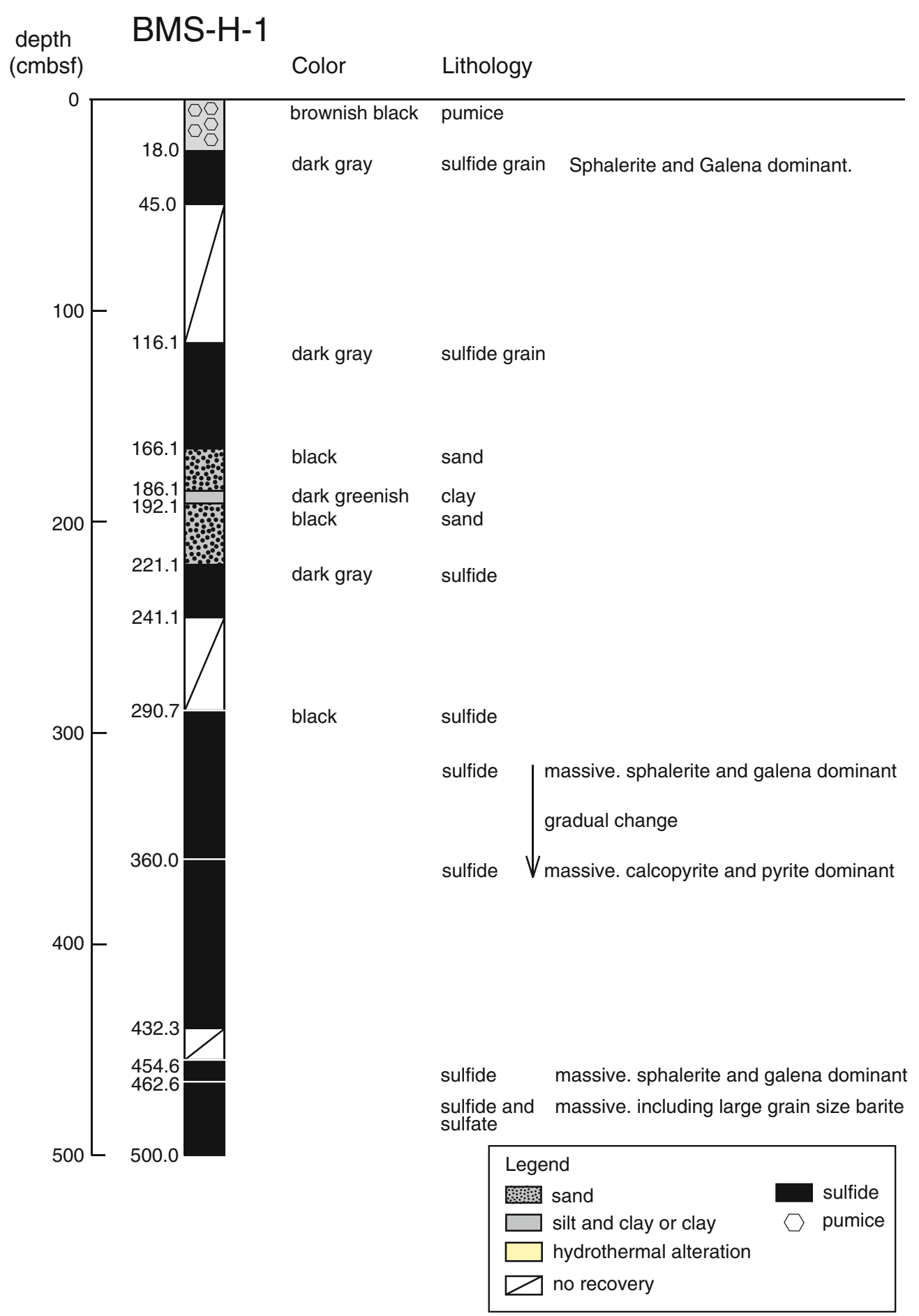

Fig. 42.3 Visual core descriptions (VCDs) of the obtained core samples. The identified minerals were confirmed and/or revised based on results of an onshore mineralogical study (Miyoshi et al., Chap. 44) 


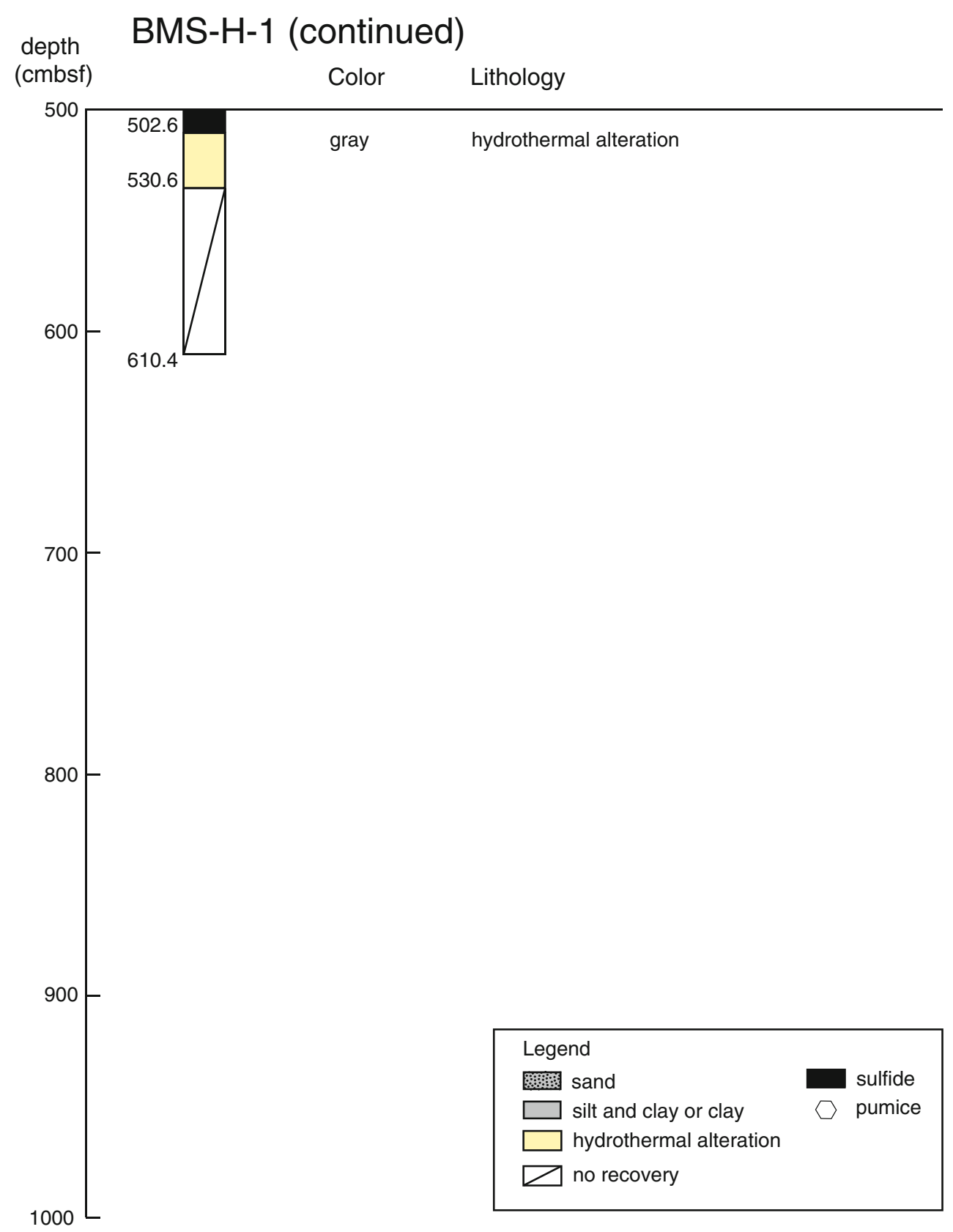

Fig. 42.3 (continued) 


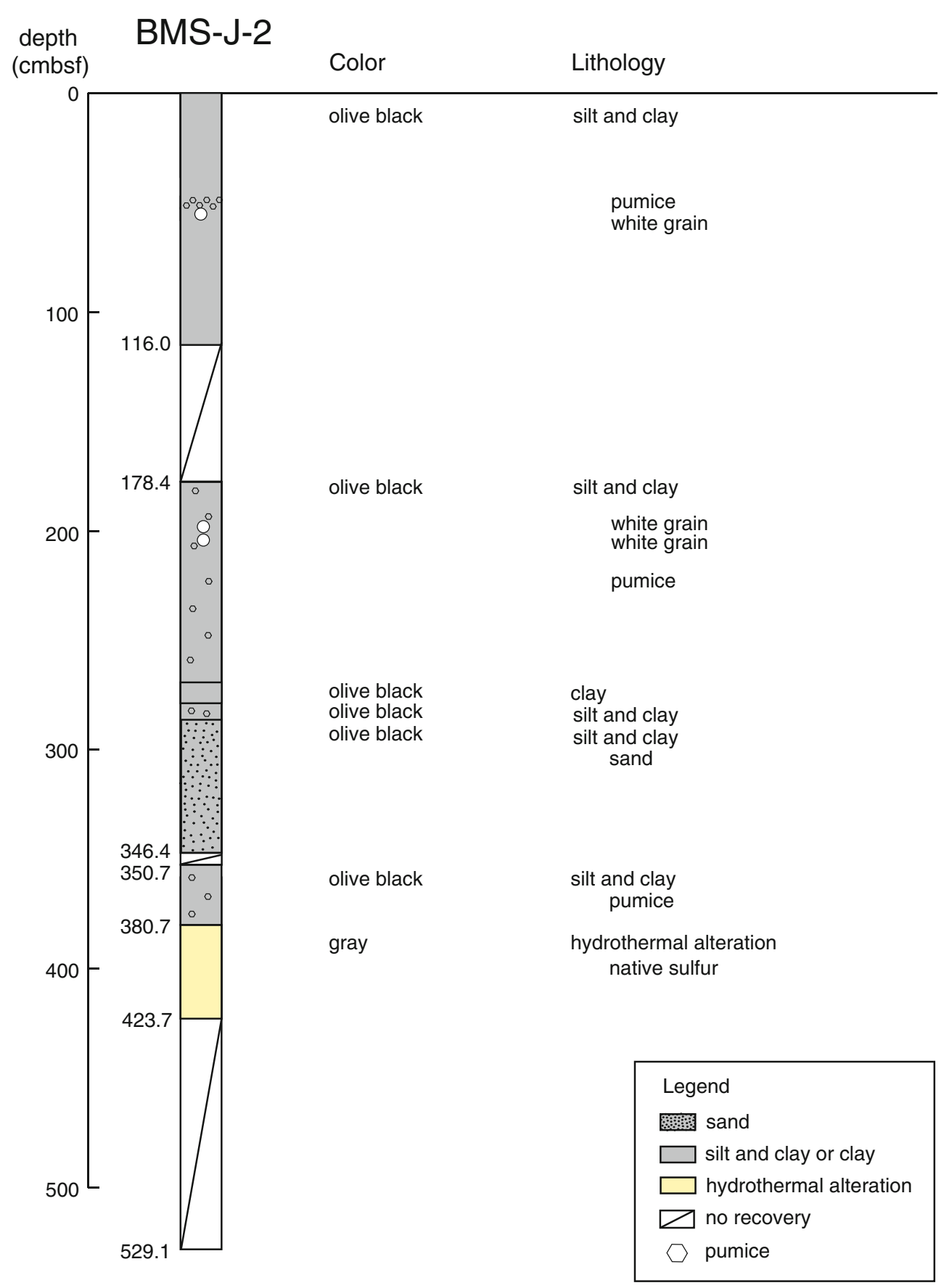

Fig. 42.3 (continued) 


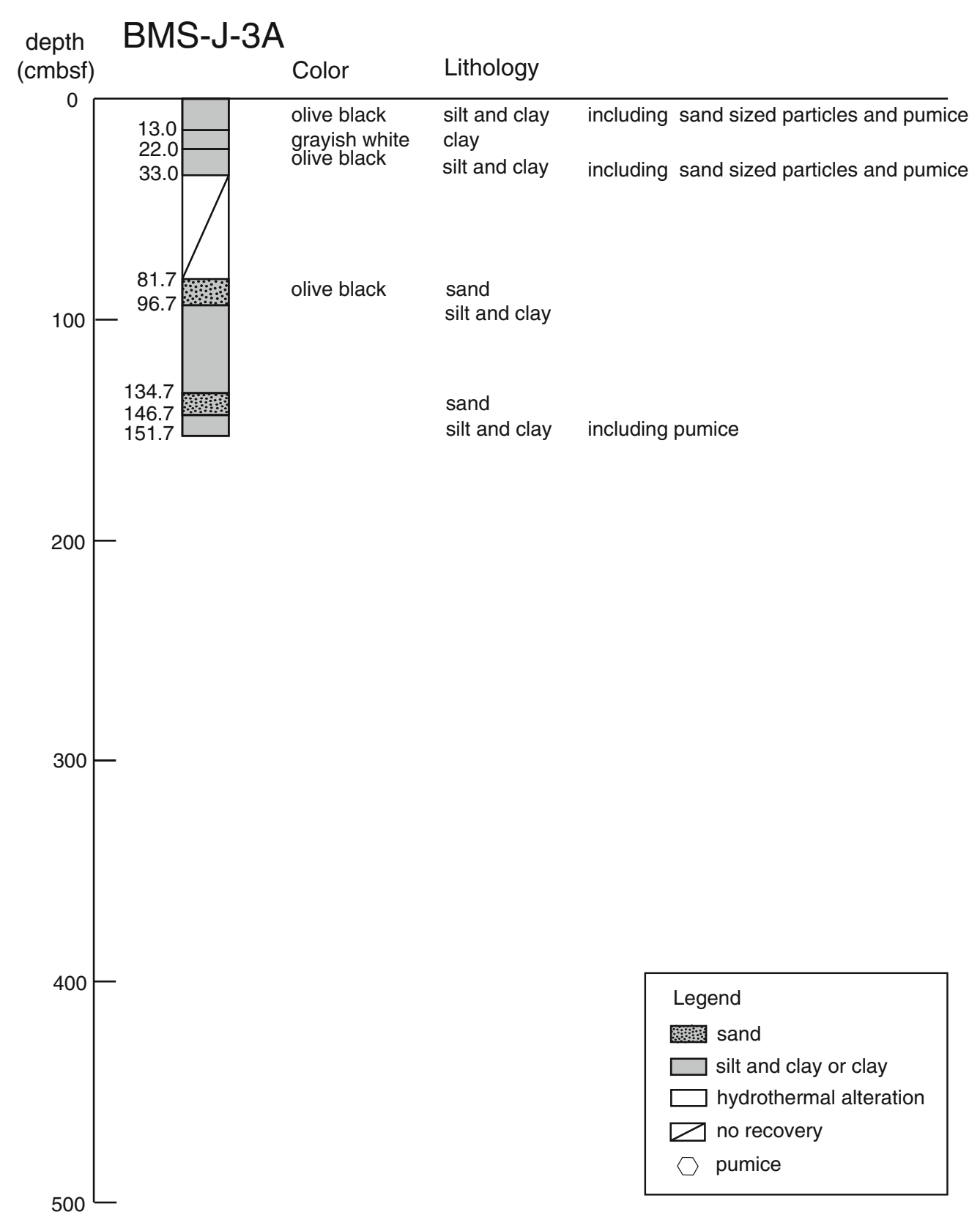

Fig. 42.3 (continued) 


\section{depth BMS-J-3B}

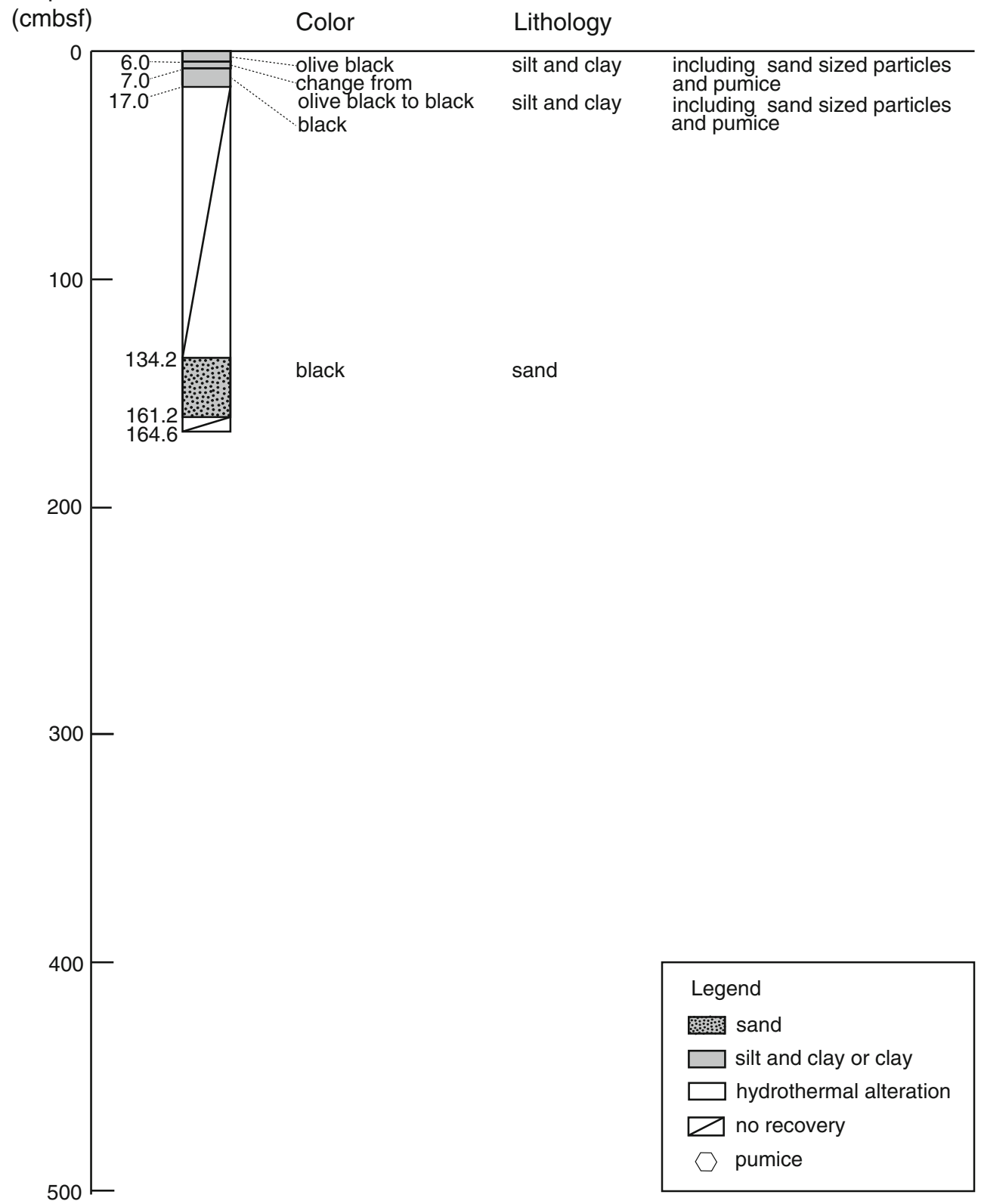

Fig. 42.3 (continued) 


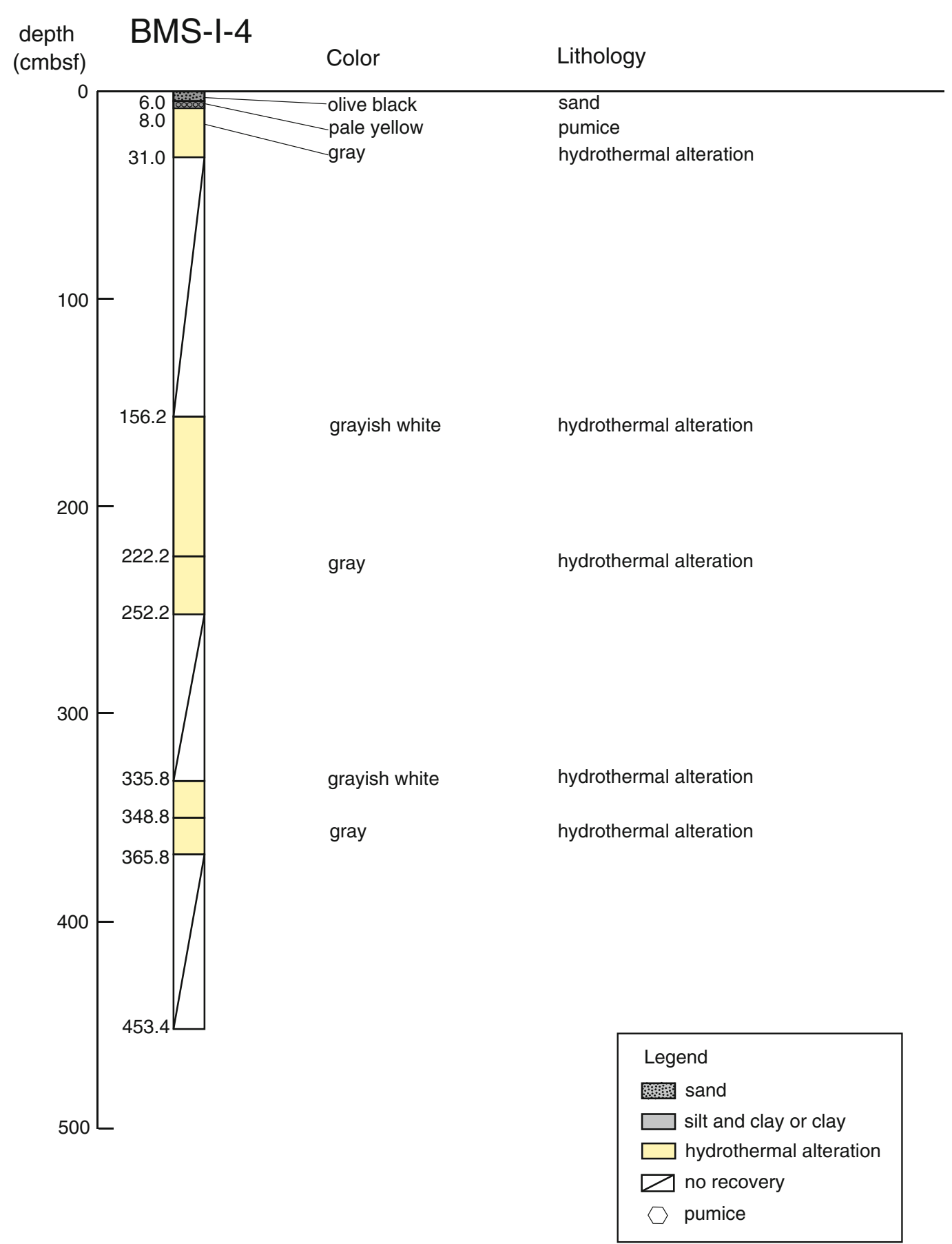

Fig. 42.3 (continued) 
BMS-J-5

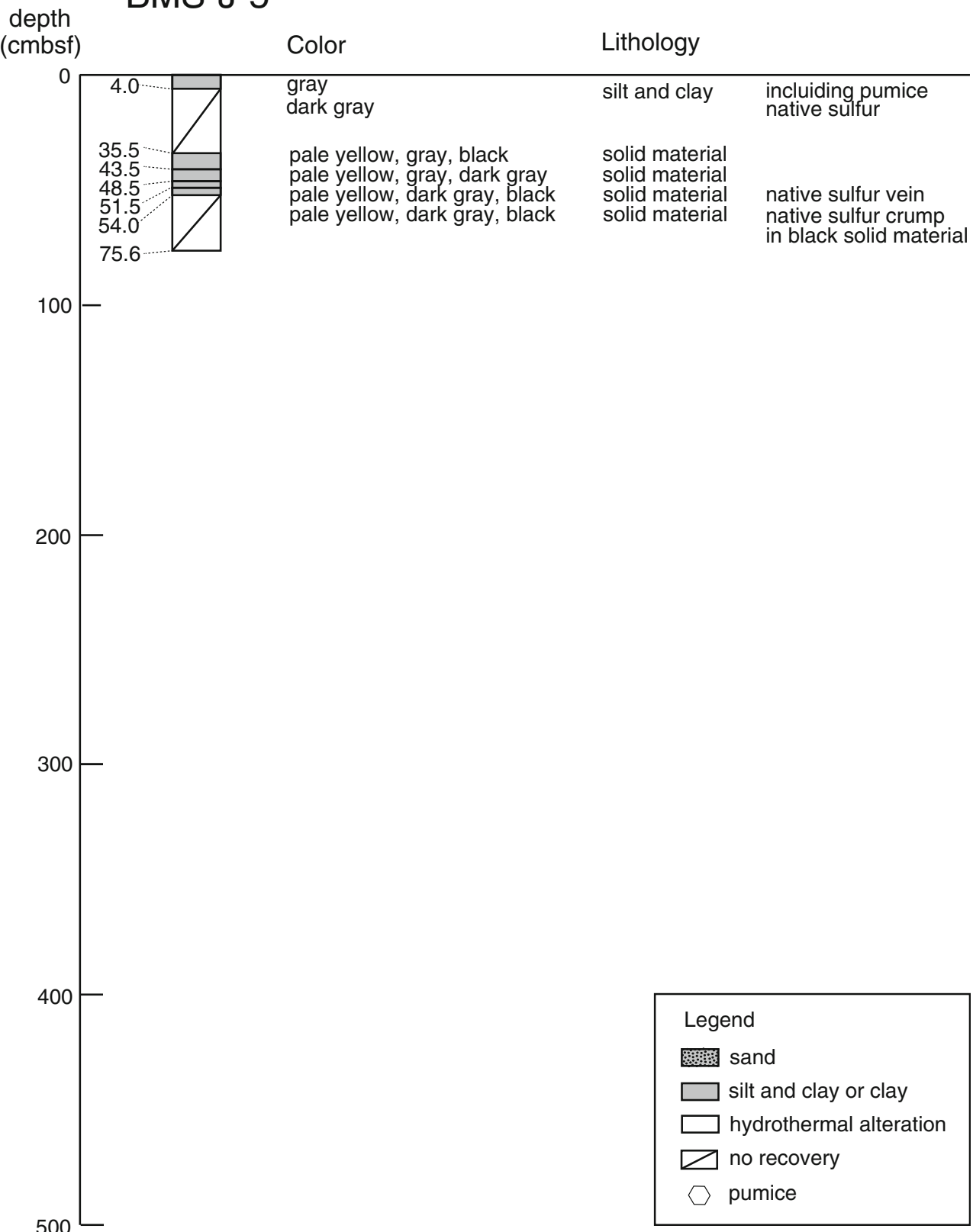

Fig. 42.3 (continued) 


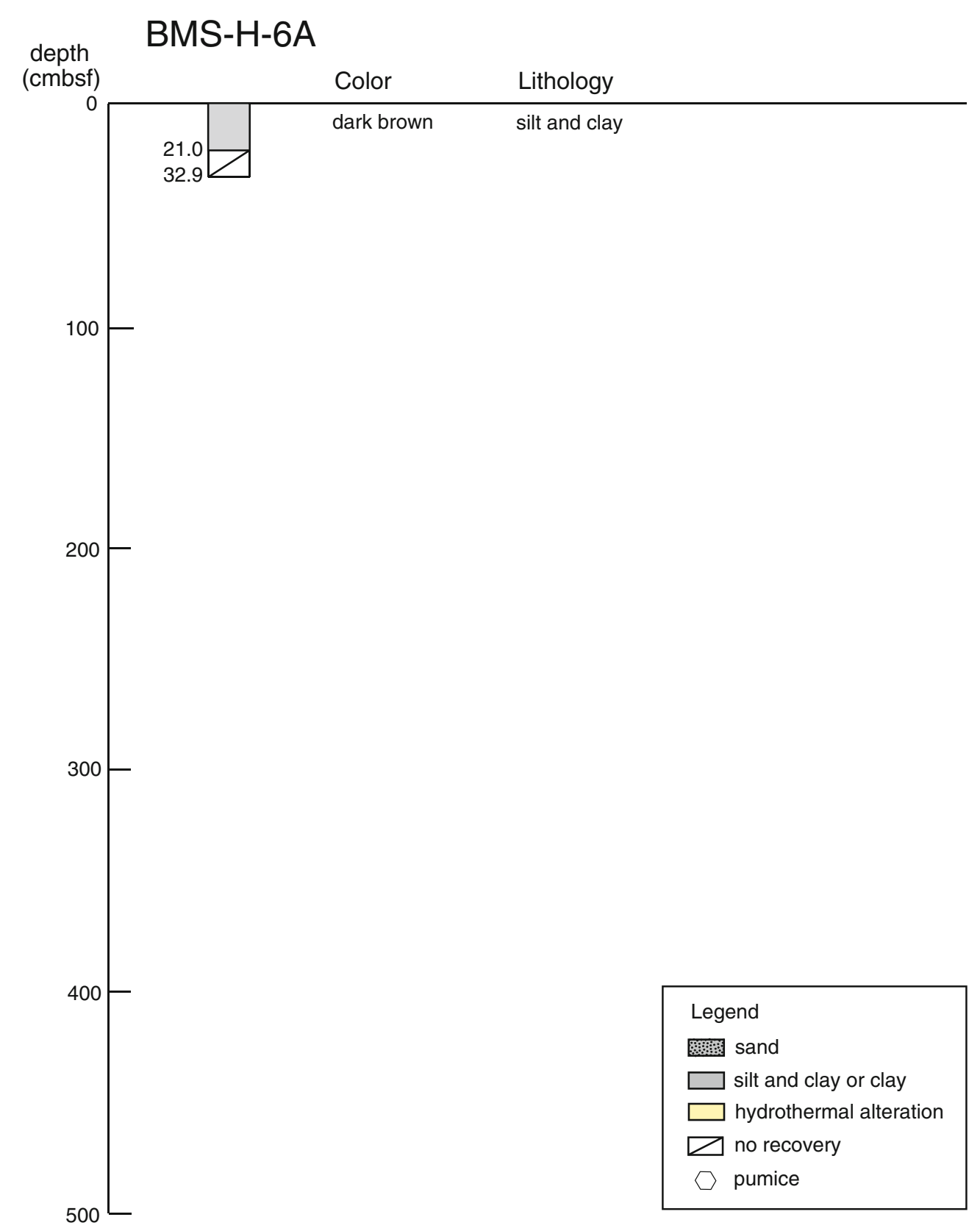

Fig. 42.3 (continued) 
depth BMS-H-6B

(cmbsf)

Color

Lithology

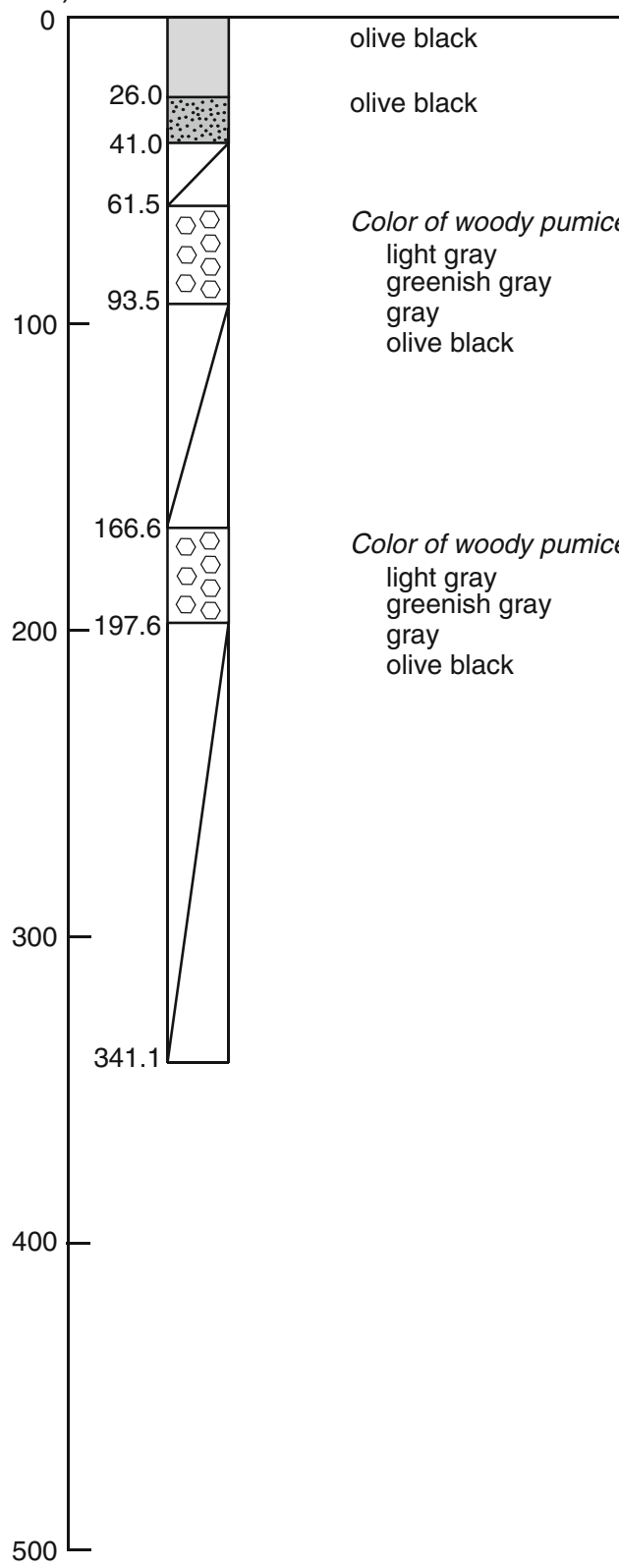

silt and clay

sand including pumice

woody pumice

light gray

greenish gray

gray

olive black

Color of woody pumice $\quad$ woody pumice

gray

gray

(a) 


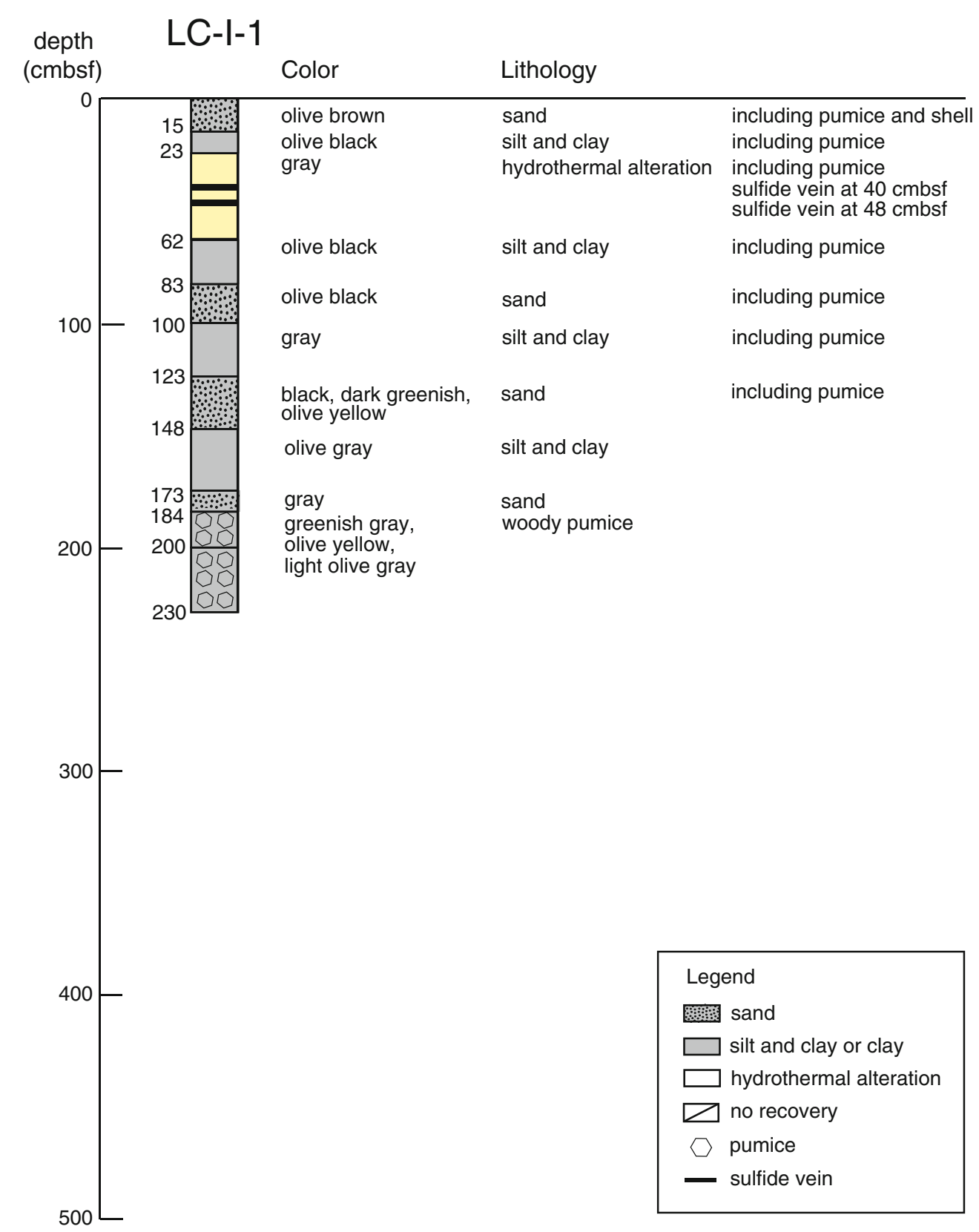

Fig. 42.3 (continued) 


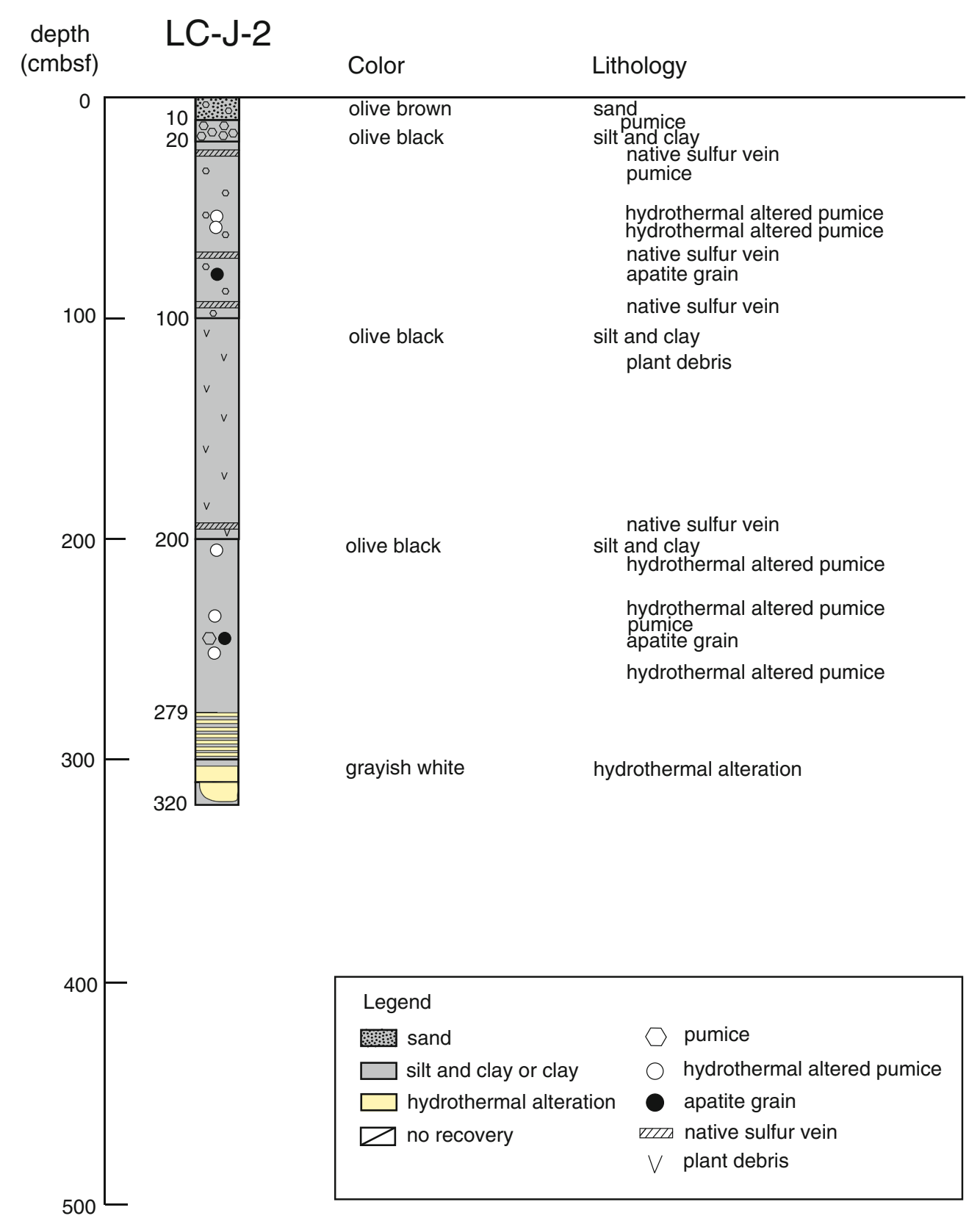

Fig. 42.3 (continued)

large size woody pumices were abundant. It is notable to recognize hydrothermally altered mud dominated from 23 to $62 \mathrm{cmbsf}$, which included sulfide veins at 40 and 48 cmbsf.

\subsubsection{Pore Fluid Chemistry}

Results of chemical analysis of pore fluid samples are summarized in Table S1 in the supplementary file. In this table, $\delta \mathrm{D}$ and $\delta^{18} \mathrm{O}$ values are expressed in per mill with SMOW and $\delta^{34} \mathrm{~S}$ values are expressed in per mill with CDT.

\subsubsection{Pore Fluid in the Hakurei Field}

Vertical profiles of pore fluid chemistry collected from the Hakurei field in the Izena Hole are illustrated in Fig. 42.4, and two components diagrams for some major species are illustrated in Fig. 42.5. Due to somehow poor core recovery, profiles from Station BMS-H-1 are rather discontinuous. In spite of the discontinuity, increase in concentration toward deep could be recognized in some major species such as $\mathrm{K}$, $\mathrm{Na}, \mathrm{Cl}$ and $\mathrm{Si}$. As discussed in the later subsection based on the pore fluid chemistry in the Iheya North Knoll field, this signature could be explained by hydration during hydrothermal alteration in the deeper layer. Observed shift in $\delta D$ 

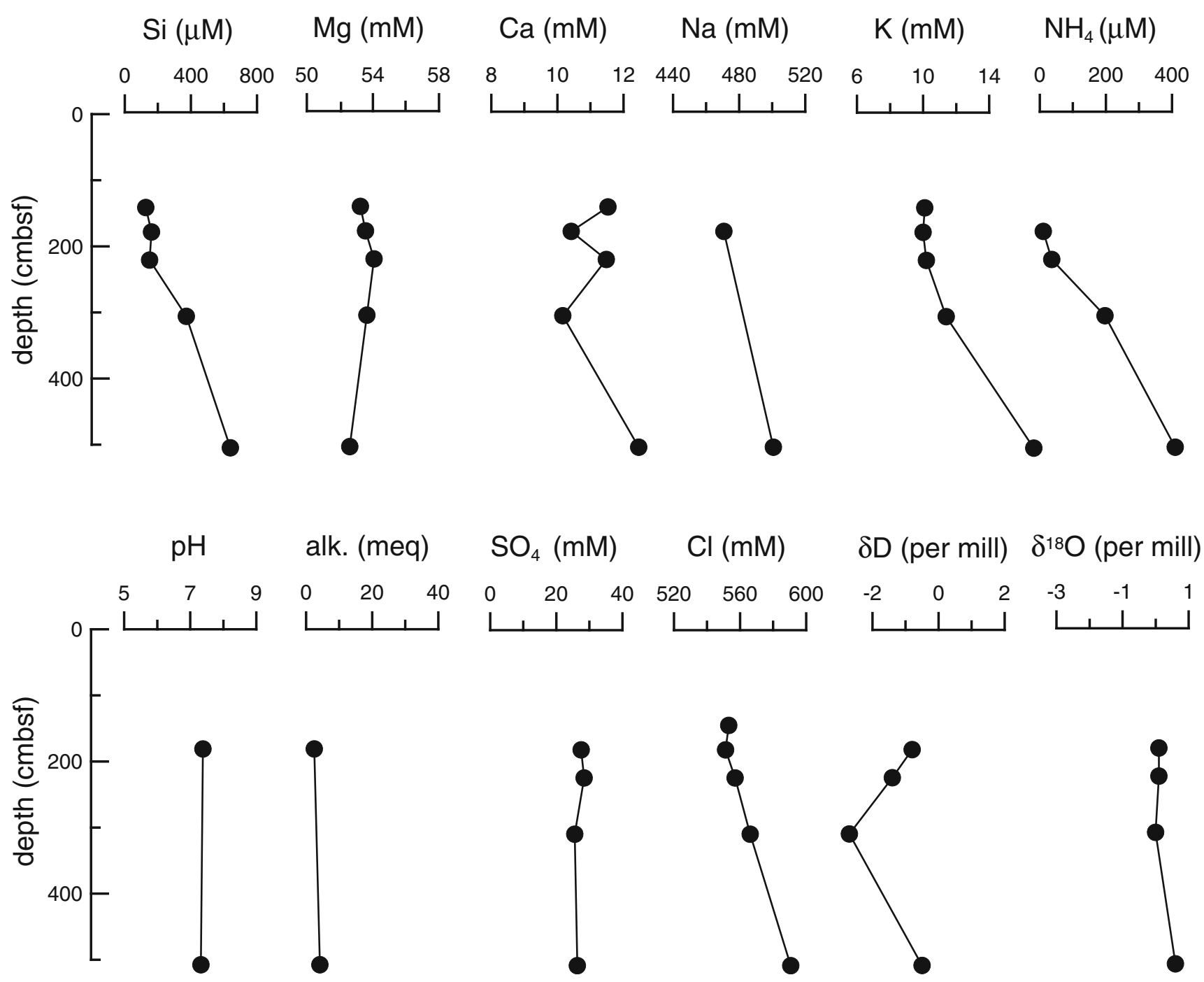

Fig. 42.4 Vertical profiles of pore fluid chemistry in the Hakurei field in the Izena Hole; closed circles represent Station BMS-H-1. Units in the figure are abbreviated as follows; cmbsf $\mathrm{cm}$ below the seafloor, $m M \mathrm{mmol} / \mathrm{L}, m e q \mathrm{meq} / \mathrm{L}, \mu M \mu \mathrm{mol} / \mathrm{L}$

values is likely to be in accordance with this idea, since it could be attributed to formation of hydroxide-bearing clay minerals. However, it is difficult to confirm this interpretation because clay mineralogy of the BMS-H-1 core has not been studied. If the above interpretation is the case, limited decrease in concentrations of $\mathrm{Mg}$ and $\mathrm{SO}_{4}$ might be considered as evidence for contribution of the hydrothermal component. While uptake of $\mathrm{H}_{2} \mathrm{O}$ by the hydration would cause proportional increase in concnetrations of all the major species, involvement of the hydrothermal component which is completely depleted in $\mathrm{Mg}$ and $\mathrm{SO}_{4}$ would balance this effect. Based on significant sulfide and sulfate mineralization noticed during the visual core observation, it would be reasonable to expect that pore fluid chemistry is affected by contribution of the hydrothermal component. However, only ambiguous evidence was recognized in the present pore fluid.

\subsubsection{Pore Fluid in the Jade Field}

Vertical profiles of pore fluid chemistry collected from the Jade field in the Izena Hole are illustrated in Fig. 42.6, and two components diagrams for some major species are illustrated in Fig. 42.7. At Station BMS-J-2, slight shift in concentration of major species toward deep might be recognized; increase in $\mathrm{Mg}, \mathrm{Ca}$ and $\mathrm{Si}$ coupled with depletion in K (closed triangles in Figs. 42.6 and 42.7). However, even below $381 \mathrm{cmbsf}$ where hydrothermal alteration minerals were obvious, these shifts are too slight. It is difficult to discuss which type of fluid interaction affects pore fluid chemistry. Also at Station BMS-J-3, pore fluid chemistry showed only slight shifts in concentration of major species (reversed triangles in Fig. 42.7).

Contrary to these, pore fluid collected from the LC-J2 core showed large shift in concentration of several chemical species (open triangles in Fig. 42.6). Decrease in $\mathrm{SO}_{4}$ 

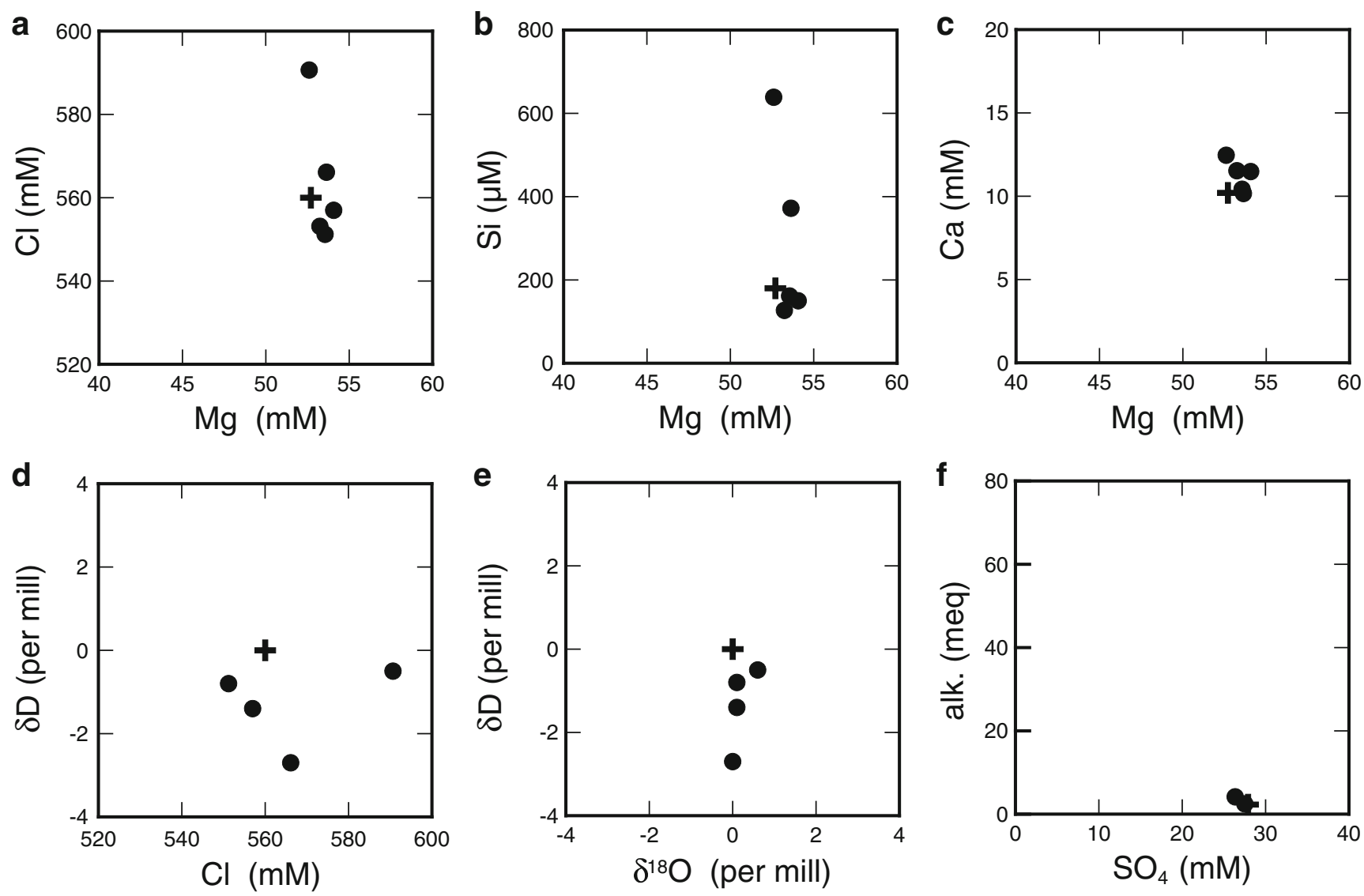

Fig. 42.5 Two components diagrams for the pore fluid samples collected from the Hakurei field: (a) $\mathrm{Cl}$ vs $\mathrm{Mg}$, (b) $\mathrm{Si}$ vs $\mathrm{Mg}$, (c) $\mathrm{Ca}$ vs $\mathrm{Mg}$, (d) $\delta \mathrm{D}$ vs $\mathrm{Cl},(\mathbf{e}) \delta \mathrm{D}$ vs $\delta^{18} \mathrm{O}$, and (f) alkalinity vs $\mathrm{SO}_{4}$. Symbols and unit abbreviations are same as in Fig. 42.4

coupled with increase in alkalinity suggests significant sulfate reduction reaction within the sediment. Sulfur isotopic composition of $\mathrm{SO}_{4}$ showed ${ }^{34} \mathrm{~S}$-eiriched signature up to $+50 \%$ o (Table S1), which supports the sulfate reduction reaction. Molar ratio between the sulfate decrease to the alkalinity increase is estimated as 2 or higher (Fig. 42.7f), which suggests the sulfate reduction utilizes organic matter as reductant. This interpretation is in accordance with that the maximum of these shifts are recognized around the depths from 100 to $200 \mathrm{cmbsf}$ where abundant plant debris was found during the visual observation. Occurrence of pyrite and native sulfur was identified by the mineralogical study (Miyoshi et al., Chap. 44), which implies these sulfur species are product of the sulfate reduction. On the other hand, profiles for other species are recognized as basically monotonous linear trend, which were characterized as increase toward deep in $\mathrm{Mg}$ and $\mathrm{Ca}$ concentrations, and as decrease in $\mathrm{Na}$ and $\mathrm{K}$ concentrations. Similar linear trends are also recognized in $\delta \mathrm{D}$ and $\delta^{18} \mathrm{O}$ values, which suggests that pore fluid chemistry at Station LC-J-2 was controlled by mixing process between two components due to elemental diffusion. This interpretation would be in accordance with the result of the visual observation, which discriminated intense grayish white colored hydrothermally altered mud below $300 \mathrm{cmbsf}$ and spotty evidence for hydrothermal alteration in the shallower sediment. If this is the case, the endmember in the deeper layer would be characterized as significant enrichment in $\mathrm{Mg}$ and $\mathrm{Ca}$, and depletion in $\mathrm{K}$. This signature cannot be explained by a result of involvement of the hydrothermal component, but could be attributed to formation and/or dissolution of alteration minerals. The mineralogical study revealed occurrence of dolomite and magnesite in the layer from 280 to $320 \mathrm{cmbsf}$ (Miyoshi et al., Chap. 44). Significant increase in $\mathrm{Mg}, \mathrm{Ca}$ and also excess alkalinity would be explained by dissolution of these carbonate minerals, although it is unknown what triggered the dissolution. The mineralogical study also identified euhedral crystals of K-feldspar in the layer from 300 to $320 \mathrm{cmbsf}$ (Miyoshi et al., Chap. 44). If substantial amount of K-feldspar forms, it would explain depletion in $\mathrm{K}$ in the pore fluid. 

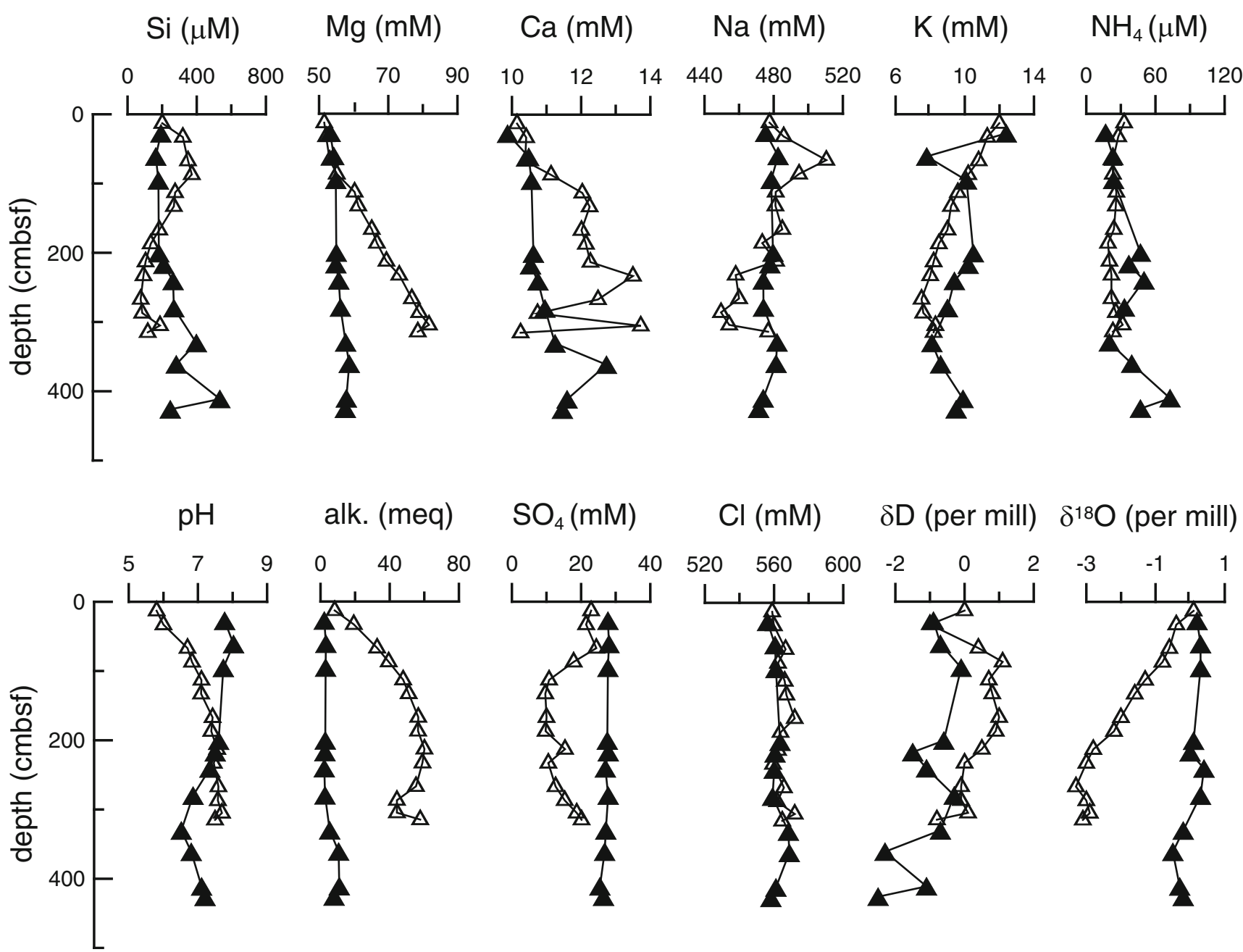

Fig. 42.6 Vertical profiles of pore fluid chemistry in the Jade field in the Izena Hole; closed triangles represent Station BMS-J-2, open triangles represent Station LC-J-2, and reverse closed triangles

\subsubsection{Pore Fluid Chemistry in the Iheya North Knoll Field}

Vertical profiles of pore fluid chemistry collected from the Iheya North Knoll field are illustrated in Fig. 42.8, and two components diagrams for some major species are illustrated in Fig. 42.9. Results of head space gas analysis which was conducted only for the BMS-I-4 core are shown in Table $\mathrm{S} 2$ in the supplementary file. Gas contents in sediment were determined for $\mathrm{CH}_{4}$ and $\mathrm{H}_{2}$, but $\mathrm{H}_{2}$ contents in the head space were lower than the detection limit ( $\sim 1 \mathrm{nmol} / \mathrm{g}$ sediment) for all the analyzed samples. At Station BMS-I-4, borehole temperature measurement was conducted and its result is shown in Table S3 in the supplementary file. The measurement was conducted at four different depths, and averaged, minimum and maximum values for 2 min measurement at each depth are represent Station BMS-J-3. Units in the figure are abbreviated as follows; cmbsf $\mathrm{cm}$ below the seafloor, $m M \mathrm{mmol} / \mathrm{L}, m e q \mathrm{meq} / \mathrm{L}, \mu M$ $\mu \mathrm{mol} / \mathrm{L}$ listed in this table. These data are illustrated as vertical profiles in Fig. 42.10.

One of notable characteristic of the pore fluid chemistry from Station BMS-I-4 is increase in concentration of major ions below $180 \mathrm{cmbsf}$ (closed diamonds in Fig. 42.8). The coincident increase would be best explained by hydration of the counterpart solid phase during hydrothermal alteration. The mineralogical study revealed occurrence of abundant kaolinite in the BMS-I-4 core (Miyoshi et al., Chap. 44), and hydrothermal alteration to form kaolinite requires hydration. Previous experimental study for isotope fractionation between kaolinite and water reported negative value for a temperature range of $0-300{ }^{\circ} \mathrm{C}$ (Gilg and Sheppard 1996), which indicates preferential uptake of $\delta \mathrm{D}$-depleted hydrogen during the hydration. Therefore, the positive $\delta \mathrm{D}$ values of the pore fluid correlated with high $\mathrm{Cl}$ concentrations are 

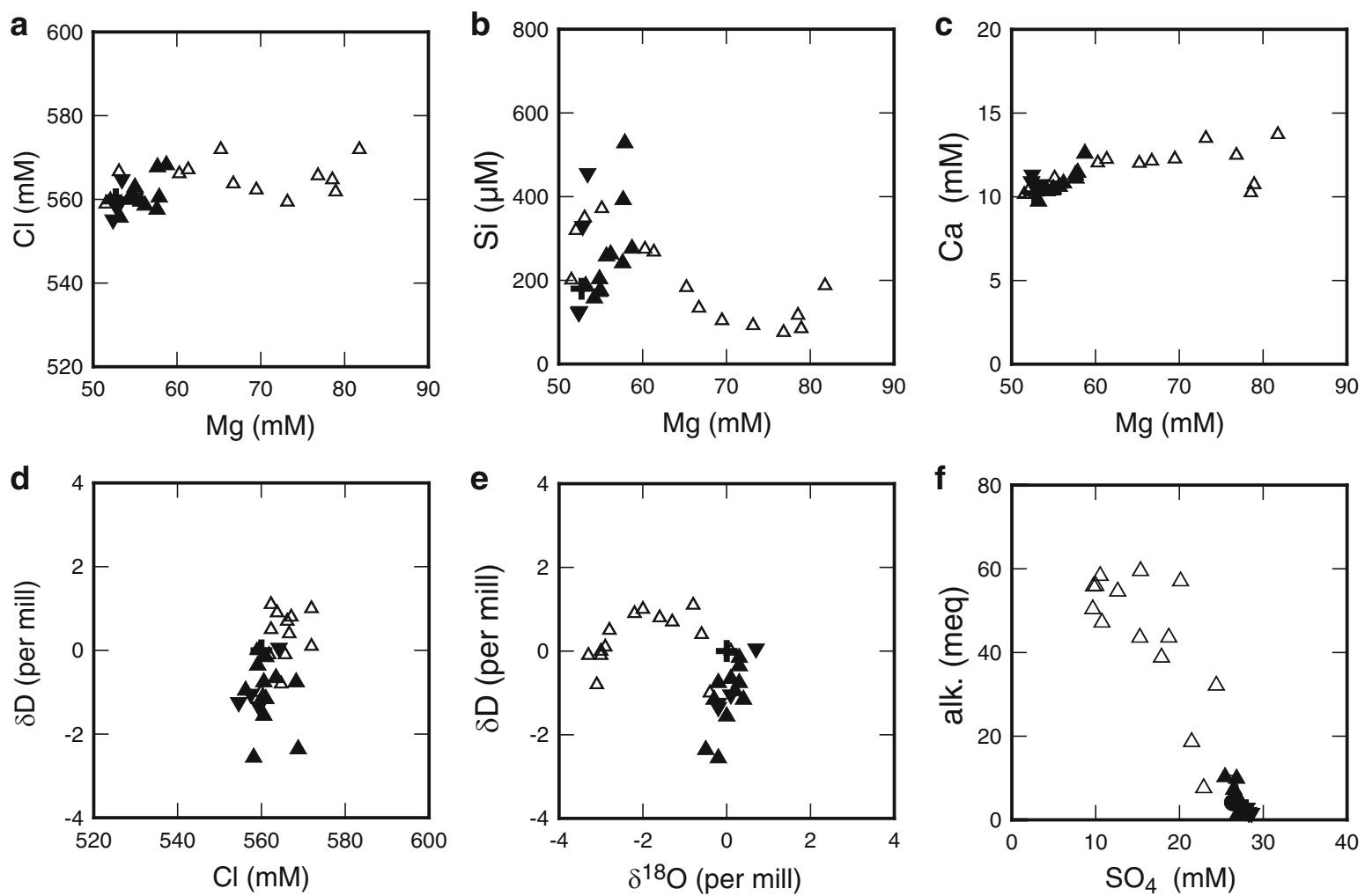

Fig. 42.7 Two components diagrams for pore fluid samples collected from the Jade field: (a) $\mathrm{Cl}$ vs $\mathrm{Mg}$, (b) $\mathrm{Si}$ vs $\mathrm{Mg}$, (c) $\mathrm{Ca}$ vs $\mathrm{Mg}$, (d) $\delta \mathrm{D}$ vs $\mathrm{Cl}$, (e) $\delta \mathrm{D}$ vs $\delta^{18} \mathrm{O}$, and (f) alkalinity vs $\mathrm{SO}_{4}$. Symbols and unit abbreviations are same as in Fig. 42.6
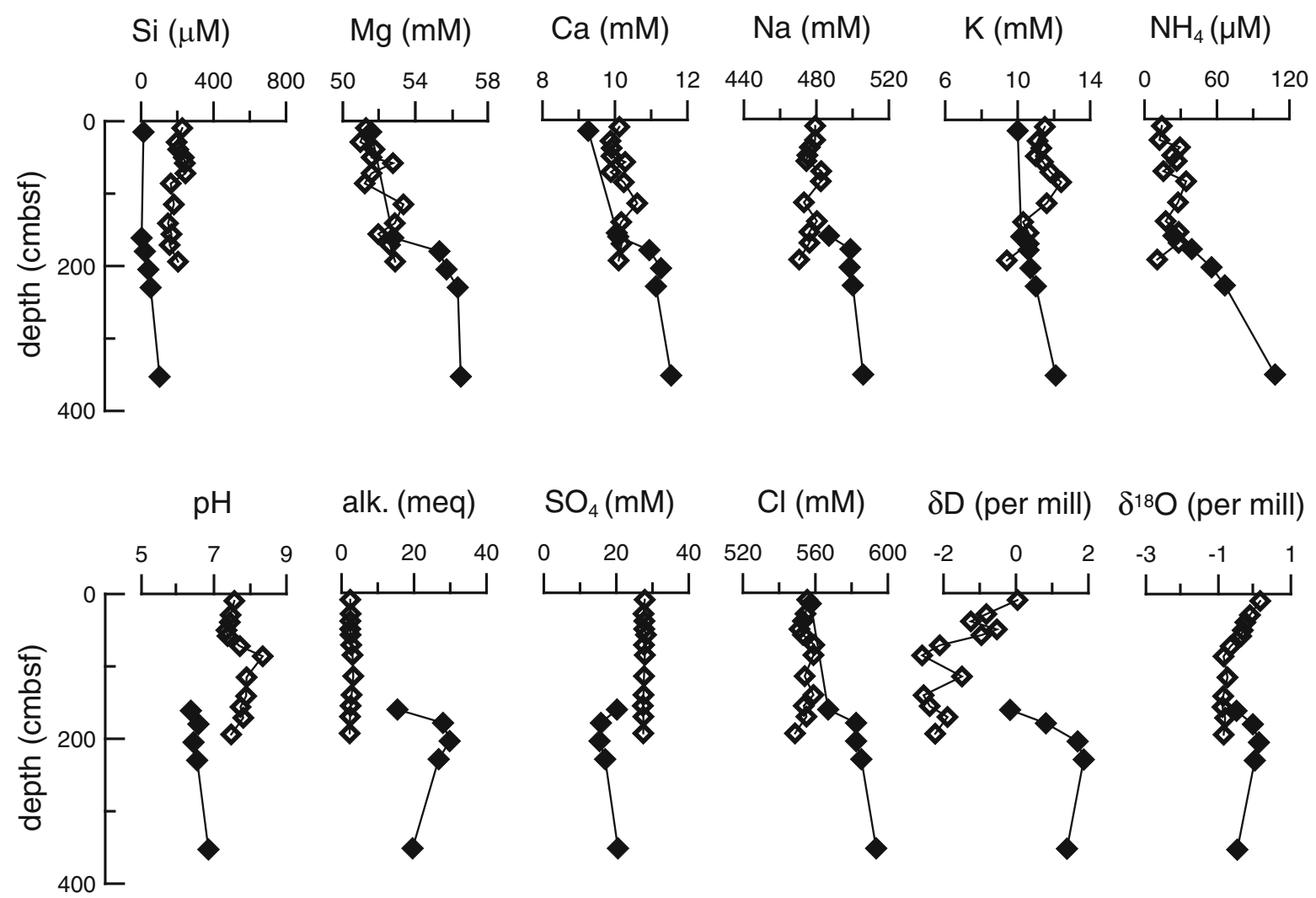

Fig. 42.8 Vertical profiles of pore fluid chemistry in the Iheya North Knoll field; closed diamonds represent Station BMS-I-4 and open diamonds represent Station LC-I-1. Units in the figure are abbreviated as follows; $c m b s f \mathrm{~cm}$ below the seafloor, $m M \mathrm{mmol} / \mathrm{L}, m e q \mathrm{meq} / \mathrm{L}, \mu M \mu \mathrm{mol} / \mathrm{L}$ 

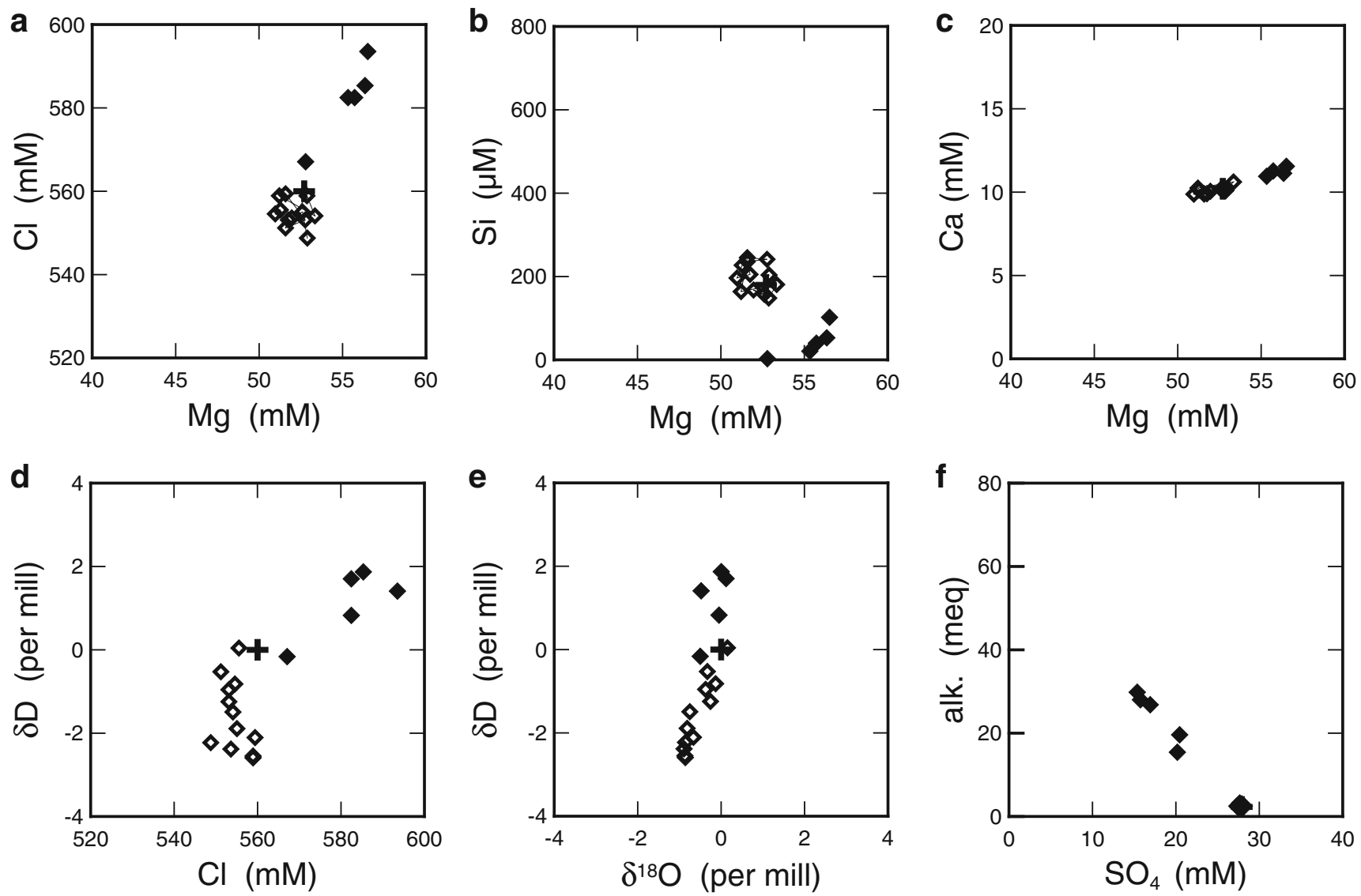

Fig. 42.9 Two components diagram for pore fluid samples in the Iheya North Knoll field: (a) $\mathrm{Cl}$ vs $\mathrm{Mg}$, (b) $\mathrm{Si}$ vs $\mathrm{Mg}$, (c) $\mathrm{Ca}$ vs $\mathrm{Mg}$, (d) $\delta \mathrm{D}$ vs $\mathrm{Cl}$, (e) $\delta \mathrm{D}$ vs $\delta^{18} \mathrm{O}$, (f) alkalinity vs $\mathrm{SO}_{4}$. Symbols and unit abbreviations are same as in Fig. 42.8

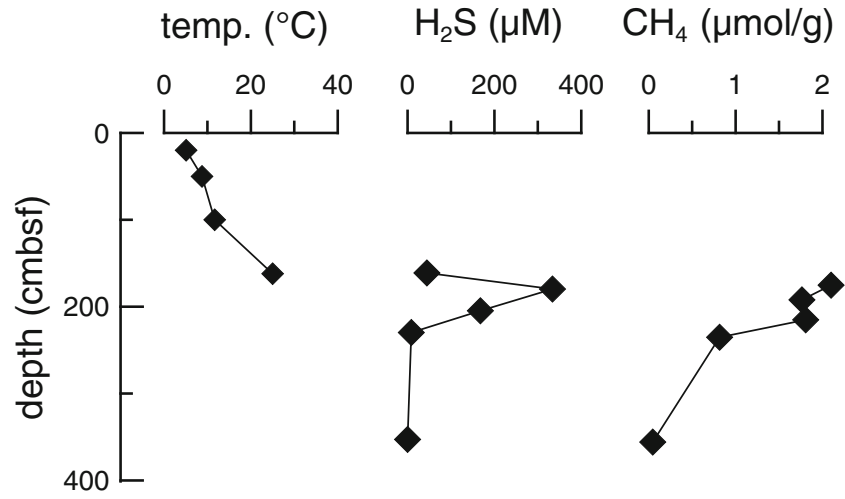

Fig. 42.10 Vertical profiles of borehole temperature, $\mathrm{H}_{2} \mathrm{~S}$ concentration in pore fluid, and $\mathrm{CH}_{4}$ content in sediment, at Station BMS-I-4 in the Iheya North Knoll field. Units in the figure are abbreviated as follows; cmbsf $\mathrm{cm}$ below the seafloor, $\mu M \mu \mathrm{mol} / \mathrm{L}$. The unit of $\mu \mathrm{mol} / \mathrm{g}$ for head space gas $\left(\mathrm{CH}_{4}\right)$ indicates $1 \mu \mathrm{mol}$ of gas specie was extracted from $1 \mathrm{~g}$ of sediment in wet base

consistent with a result of the hydration reaction (Fig. 42.9). As another characteristic of the pore fluid, rather high contents of $\mathrm{CH}_{4}$ and $\mathrm{H}_{2} \mathrm{~S}$ were detected at depths from 170 to $220 \mathrm{cmbsf}$, which is basically in accordance with observation of gas bubbling from the core samples after recovery. Enrichment in these gas species might be related to high gas concentrations in the hydrothermal fluid of the Iheya North Knoll field (Kawagucci et al. 2011). However, no evidence for input of the hydrothermal component was recognized among the major species (Fig. 42.9). Moreover, results of the borehole measurement suggested that in situ temperature in the corresponding depths is likely to be not so high but around a range from 30 to $60{ }^{\circ} \mathrm{C}$ (Fig. 42.10). On the other hand, slight decrease in $\mathrm{SO}_{4}$ concentration coupled with increase in alkalinity is recognized at depths from 170 to 220 cmbsf, which suggests sulfate reduction reaction. Enrichment in $\mathrm{H}_{2} \mathrm{~S}$ in the pore fluid would be explained better as a result of production of the sulfate reduction. Since the slope between alkalinity increases to $\mathrm{SO}_{4}$ decrease is estimated as 2 , the enriched $\mathrm{CH}_{4}$ in the corresponding layer is unlikely to act as the reductant.

Pore fluid chemistry at Station LC-I-1 showed basically no significant deviation from that of seawater (open diamonds in Fig. 42.8). On the other hand, correlated shift between $\delta D$ and 
$\delta^{18} \mathrm{O}$ values is clearly recognized (Fig. 42.9). It is difficult to discuss which type of fluid interactions affects pore fluid chemistry based on this data set.

\subsection{Summary}

Shallow drilling provided us an opportunity to study geochemical environment just below the seafloor of an active hydrothermal field using core samples. Evidence for intense hydrothermal alteration was recognized obviously in three cores; collected from the BMS-I-4 in the Iheya North Knoll field, collected from the LC-J-2 and BMS-J-2 in the Jade field. Evidence for sulfide and sulfate mineralization was obvious in one core, collected from the BMS-H-1 in the Hakurei field. Pore fluid chemistry at Station BMS-I-4 showed coincident increase in many major species. This signature is attributed to hydration reaction during hydrothermal alteration to form kaolinite. Pore fluid chemistry at Station LC-J-2 showed monotonous linear profiles in many major species. This signature is attributed to as a result of dissolution of carbonate minerals in the hydrothermal alteration layer. Contrary to them, pore fluid chemistry at BMS-J2 did not show substantial shifts in the vertical profile. Pore fluid chemistry at BMS-H-1 showed only slight shifts in the vertical profile which could not well correlated to hydrothermal alteration interactions. Moreover, evidence for involvement of the hydrothermal component into pore fluid was not clearly recognized in all the cores examined in this study.

Acknowledgements We are grateful to Captain Morio Endo and crew of R/V Hakurei-Maru No.2, also to the team leader Tadashi Sato and members of the BMS operation team for their professional skill and careful consideration for collecting core samples. This study was supported by the "TAIGA project," which was funded by a Grant-inAid for Scientific Research on Innovative Areas (\#2010900120109006) from the Ministry of Education, Culture, Sports, Science and Technology (MEXT), Japan.

Open Access This chapter is distributed under the terms of the Creative Commons Attribution Noncommercial License, which permits any noncommercial use, distribution, and reproduction in any medium, provided the original author(s) and source are credited.

\section{References}

Gieskes JM, Gamo T, Brumsack H (1991) Chemical methods for interstitial water analysis aboard JOIDES Resolution. ODP Tech Note, p 15

Gilg HA, Sheppard MF (1996) Hydrogen isotope fractionation between kaolinite and water revisited. Geochim Cosmochim Acta 60:529-533

Ishibashi J, Urabe T (1995) Hydrothermal activity related to arc-backarc magmatism in the Western Pacific. In: Taylor B (ed) Back-arc basin: tectonics and magmatism. Plenum, New York, pp 451-495

Kato Y (1987) Woody pumice generated with submarine eruption. J Geol Soc Jpn 98:11-20

Kawagucci S, Chiba H, Ishibashi J, Yamanaka T, Toki T, Muramatsu Y, Ueno Y, Makabe A, Inoue $\mathrm{K}$, Yoshida N, Nakagawa S, Nunoura T, Takai K, Takahata N, Sano Y, Narita T, Teranishi G, Obata H, Gamo T (2011) Hydrothermal fluid geochemistry at the Iheya North field in the mid-Okinawa Trough: implication for origin of methane in subseafloor fluid circulation systems. Geochem J 45:109-124

Kawagucci S, Ueno Y, Takai K, Toki T, Ito M, Inoue K, Makabe A, Yoshida N, Muramatsu Y, Takahata N, Sano Y, Narita T, Teranishi G, Obata H, Nakagawa S, Nunoura T, Gamo T (2013) Geochemical origin of hydrothermal fluid methane in sediment-associated fields and its relevance to the geographical distribution of whole hydrothermal circulation. Chem Geol 339:213-225

Marumo K, Urabe T, Goto A, Takano Y, Nakaseama M (2008) Mineralogy and isotope geochemistry of active submarine hydrothermal field at Suiyo Seamount, Izu-Bonin Arc, West Pacific Ocean. Res Geol 58:220-248. doi:10.1111/j.1751-3928.2008.00059.x

Manheim FT, Sayles FL (1974) Composition and origin of interstitial waters of marine sediments, based on deep sea drill cores. In: Goldberg ED (ed) The sea, vol 5, Marine chemistry: the sedimentary cycle. Wiley, New York, pp 527-568

Nakaseama M, Ishibashi J-I, Ogawa K, Hamasaki H, Fujino K, Yamanaka $\mathrm{T}$ (2008) Fluid-sediment interaction in a marine shallow-water hydrothermal system in the Wakamiko submarine crater, south Kyushu, Japan. Res Geol 58:289-300. doi:10.1111/j. 1751-3928.2008.00062.x

Sakai H, Gamo T, Kim E-S, Tsutsumi M, Tanaka T, Ishibashi J, Wakita H, Yamano M, Oomori T (1990) Venting of caron dioxide-rich fluid and hydrate formation in mid-Okinawa Trough Backarc Basin. Science 248:1093-1096

Takai K, Mottl MJ, Nielsen SH, The IODP Expedition 331 Scientists (2012) IODP Expedition 331: strong and expansive subseafloor hydrothermal activities in the Okinawa Trough. Sci Drill 13:19-27. doi:10.2204/iodp.sd.13.03.2011

Yamanaka T, Mizota C, Matsuyama-Serisawa K, Kakegawa T, Miyazaki J, Mampuku M, Tsutsumi H, Fujiwara Y (2008) Stable isotopic characterization of carbon, nitrogen and sulfur uptake of Acharax japonica from central Japan. Plankton Benthos Res 3:36-41 